\title{
Relative sea level changes and development of the Hiiumaa Island, Estonia, during the Holocene
}

\author{
Jüri VASSILJEV ${ }^{1, *}$, Leili SAARSE ${ }^{1}$, leva GRUDZINSKA ${ }^{1}$ and Atko HEINSALU ${ }^{1}$ \\ 1 Tallinn University of Technology, Institute of Geology, Ehitajate tee 5, 19086 Tallinn, Estonia
}

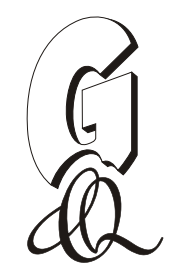

\begin{abstract}
Vassiljev, J., Saarse, L., Grudzinska, I., Heinsalu, A., 2015. Relative sea level changes and development of the Hiiumaa Island, Estonia, during the Holocene. Geological Quarterly, 59 (3): 517-530, doi: 10.7306/gq.1227

Three sediment cores (Loopsoo, Tihu, Prassi) from Hiiumaa Island (Estonia) were investigated using diatoms, lithological proxies, magnetic susceptibility, geochronological dates and incorporated with the previously studied Kõivasoo site, aiming to reconstruct the development of the island and shoreline changes during the Litorina Sea and the Limnea Sea. The highest level of the Litorina Sea shoreline near Kõivasoo is at $27.6 \mathrm{~m}$ a.s.l., and it occurred during the Initial Litorina Sea. Within the Litorina Sea transgression, 7800 cal yr BP, relative sea level reached $24.9 \mathrm{~m}$ a.s.l. at Kõivasoo, $24.1 \mathrm{~m}$ a.s.I. at Loopsoo, $23.6 \mathrm{~m}$ a.s.I. at Tihu, and $21.5 \mathrm{~m}$ a.s.l. at Prassi. Kõivasoo became isolated from the sea about $8500 \mathrm{cal}$ yr BP, Loopsoo between 7100 and $6800 \mathrm{cal} \mathrm{yr} \mathrm{BP,} \mathrm{Tihu} \mathrm{around} 4800 \mathrm{cal} \mathrm{yr} \mathrm{BP}$, and Prassi about $2500 \mathrm{cal}$ yr BP. Presently gained data from Hiiumaa Island confirm that the Litorina Sea regressed consistently during the last 8000 years due to progressively declining isostatic rebound. The present study is also illustrated by 3-dimensional palaeogeographic maps of the Hiiumaa Island development.
\end{abstract}

Key words: Litorina Sea, Limnea Sea, lithology, diatoms, relative sea level changes, Estonia.

\section{INTRODUCTION}

Large islands in the Baltic Sea Basin (BSB) have long time attracted interest of researches as they show marginality in geological and vegetation history and climate conditions (e.g., Luha et al., 1934; Königsson, 1968; Sepp, 1974; Svensson, 1989). Hiiumaa Island experienced significant coastline changes during the Holocene due to interplay between sea level change and isostatic land uplift (Kessel and Raukas, 1967, 1979; Sepp, 1974; Saarse, 1994; Raukas and Ratas, 1996; Hang and Kokovkin, 1999; Saarse et al., 2003). The Ancylus Lake and the Litorina Sea, stages of the BSB, left behind numerous beach ridges, wide spectrum of scarps, and several ancient lagoons, which are potential sites to study water level changes, island development and early human colonization (Kriiska and Lõugas, 1999). Coastal formations of the Ancylus Lake are now positioned up to $45 \mathrm{~m}$ a.s.I., that of the Litorina Sea up to $27.6 \mathrm{~m}$, and of the Limnea Sea up to $12.8 \mathrm{~m}$ a.s.I. (Kents, 1939), proceeded from the postglacial land uplift that is nowadays approximately $2.5 \mathrm{~mm} \mathrm{yr}^{-1}$ on Hiiumaa (Torim, 2004).

The current study focuses on the development of the Litorina Sea whose onset is marked with the establishment of the connection between the BSB and the ocean around

\footnotetext{
* Corresponding author, e-mail: jyri.vassiljev@ttu.ee Received: September 24, 2014; accepted: March 19, 2015; first published online: April 9, 2015
}

9800 cal yr BP (Andrén et al., 2000; Berglund et al., 2005), since when the water levels in the BSB and the ocean were in equilibrium. The Mastogloia Sea has been recognized between the freshwater Ancylus Lake and the brackish-water Litorina Sea as a transitional diatom-stratigraphic unit (Kessel and Pork, 1974; Cker et al., 1988; Hyvärinen et al., 1988, 1992; Haila et al., 1991) based on the presence of weakly brackish-water diatom assemblages particularly in the littoral sequences (Hyvärinen, 1984, 2000), whereas in the offshore sequences such a transitional unit is commonly absent (Ignatius et al., 1981). Lately, this sub-stage was renamed Early (Initial) Litorina Sea, marking penetration of saline water to the BSB about 9800-8500 cal yr BP (Andrén et al., 2000; Berglund et al., 2005; Harff et al., 2011). The slightly brackish-water diatoms occur in the sediment sequences of Finland since $8800 \mathrm{cal}$ yr BP (Eronen, 1974), and about $8500 \mathrm{cal}$ yr BP in western Estonia (Hyvärinen et al., 1988). However, the typical brackish-water mollusc fauna migrated later, when the salinity of the sea had reached 15-20\%。 (Hyvärinen et al., 1988). The transgression peak of the Litorina Sea is time-transgressive occurring later in the southern parts of the BSB, i.e. in areas with a slower land uplift rate (Miettinen and Hyvärinen, 1997; Hyvärinen, 2000; Saarse et al., 2000; Miettinen, 2002, 2004).

The current paper summarizes the main results of lithostratigraphical and diatom biostratigraphical analysis, and ${ }^{14} \mathrm{C}$ radiocarbon dating applied to studies of shore displacement on the Island of Hiiumaa. These data from four isolated basins is then used in GIS-analysis with aim to reconstruct the development of Hiiumaa Island and to illustrate its 3-dimensional (3D) palaeogeographic maps. 


\section{MATERIAL AND METHODS}

\section{STUDY AREA AND SITE DESCRIPTION}

In the current study, three basins: Tihu, Loopsoo and Prassi (Fig. 1) were examined and incorporated with the earlier study by Königsson et al. (1998) and Saarse et al. (2000) from Kõivasoo.

Kõivasoo is a small raised bog, an ancient Litorina Sea lagoon on the Kõpu Peninsula at $27.5 \mathrm{~m}$ a.s.l. (Fig. 1B), surrounded by wide spectrum of sandy beach formations. It has a narrow threshold in the south at an elevation of $27 \mathrm{~m}$ a.s.l., which was deepened by ditching the bog. Pollen and diatom records of Kõivasoo deposits, taken from the central part (5854'32”'N; 22¹1'56”'E), were published earlier (Sarv, 1981; Sarv et al., 1982; Königsson et al., 1998; Saarse et al., 2000).
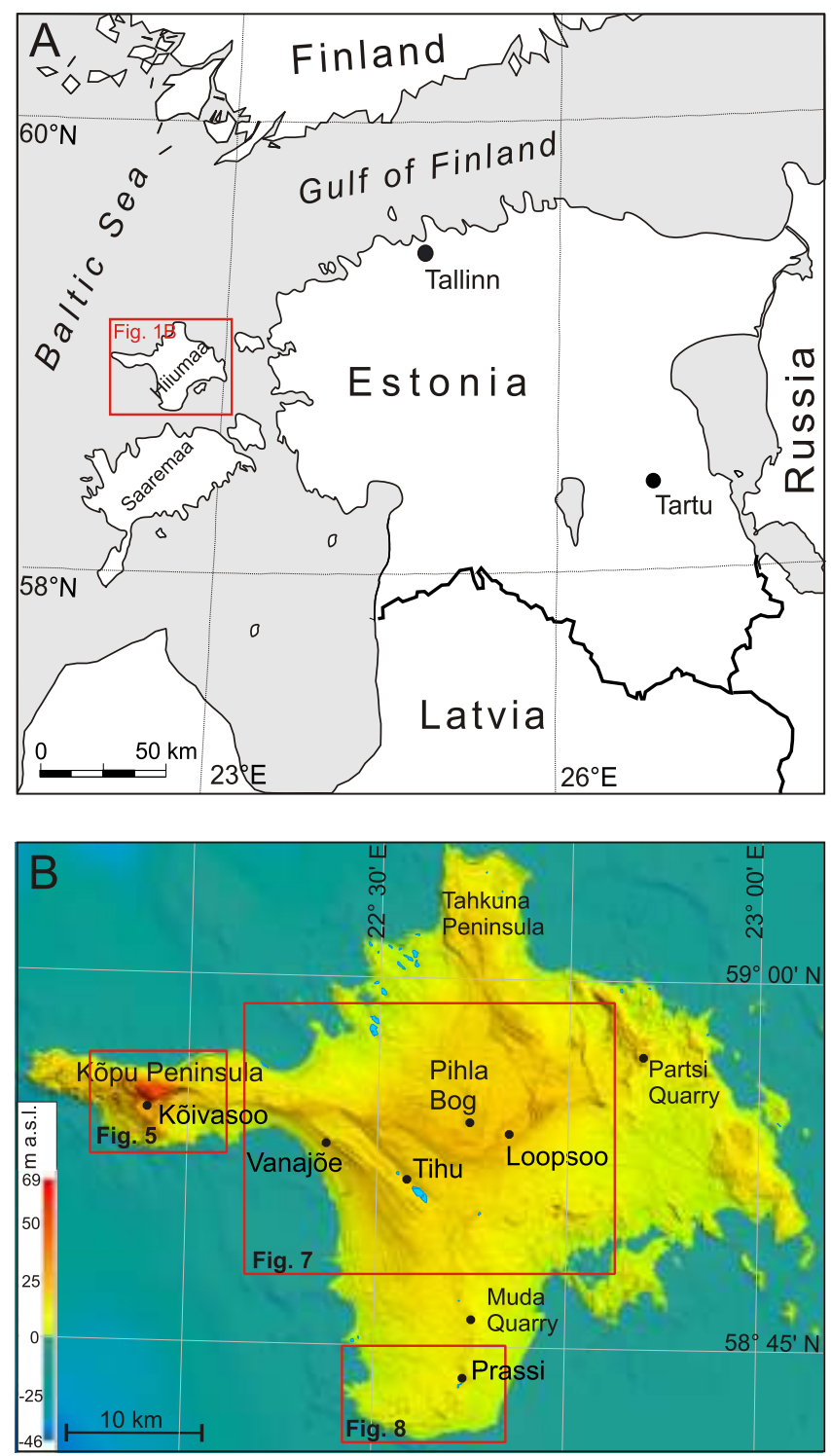

Fig. 1. Overview map of the study area $(A)$ and digital terrain model (DTM) of Hiiumaa Island (B)

Black dots mark the study sites and red squares the areas of palaeogeographical reconstruction
Archaeological remains found on the beach ridges east to Kõivasoo reveal a seasonal settlement during the Late Mesolithic and Early Neolithic (Kriiska and Lõugas, 1999). Typical Litorina Sea mollusc fauna has been identified near the settlement site at $26 \mathrm{~m}$ a.s.I. (Moora and Lõugas, 1995). More details about the pollen stratigraphy and radiocarbon dates are given in Königsson et al. (1998), and the development of the Kõpu peninsula is discussed by Saarse et al. (2000).

Loopsoo Bog is located in the central part of Hiiumaa (Fig. $1 \mathrm{~B})$, close to the Ordovician and Silurian bedrock boundary (Eltermann, 1993a). The present bog surface lies at 21.5-22 m a.s.l., has an area of 128 ha and is surrounded by a bowshaped beach ridge. The presently observed threshold at $21 \mathrm{~m}$ a.s.l. at the outflow ditch in the eastern part of the bog was probably ca. $1 \mathrm{~m}$ lower and was covered by sand during isolation. Samples for the current study were taken from the southern part

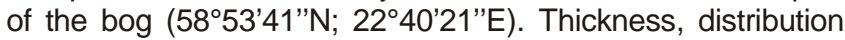
and properties of the peat were studied by Orru (1995), but the peat layers were not dated. Loopsoo is surrounded by a thin woody rim and field patches. The nearest dated site is Pihla Bog (Fig. 1B), 2 km north-west of Loopsoo, where the basal peat at the contact with sand at about $14 \mathrm{~m}$ a.s.l. has been dated to $3530 \pm 230 \mathrm{cal}$ yr BP (Liiva et al., 1966).

Lake Tihu Keskjärv (hereafter Tihu) in the western part of Hiiumaa is a small, elongated, shallow (maximum water depth $0.6 \mathrm{~m}$ ) overgrowing (2.7 ha) semidystrophic lake in a paludified valley-like depression at $14.5 \mathrm{~m}$ a.s.l. (Fig. 1B). It is flanked by ridges and dunes reaching up to $27 \mathrm{~m}$ a.s.l., and shoaling towards the south-east. The base of the nearest beach ridge was levelled at $15.5 \mathrm{~m}$ a.s.I. (Ratas, 1976), and a threshold at $14.4 \mathrm{~m}$ a.s.I. is located in the southeastern part of the valley. Here, brownish till with erratic clasts and marine sands is widely distributed, and modern topography is broken by numerous beach ridges, spits and fan-like bars (Ratas, 1976; Eltermann, 1993b). Lake shores are peaty, and the catchment is paludified and mostly forested by pine. Two ditches drain into the lake and one outlet ditch to Tihu Suurjärv. Earlier studies on the Tihu lakes include those of Thomson (1929), Mäemets (1977) and Saarse (1994). The presently studied sediment core was taken from the SE paludified part of the lake (58'51'48' $\mathrm{N}$; $\left.22^{\circ} 32^{\prime} 24^{\prime \prime} \mathrm{E}\right)$. The nearest dated section is from Vanajõe (Fig. 1B), $7 \mathrm{~km} \mathrm{NW}$ of Tihu, where the Litorina Sea mollusc shells from ca. 10-12 m a.s.l. were dated to $3050 \mathrm{yr}$ BP using the electron spin resonance (ESR) method (Molodkov and Raukas, 1996).

Lake Prassi is a small seepage lake $(7.5$ ha and $7.2 \mathrm{~m}$ a.s.I.) in the southern part of Hiiumaa (Fig. 1B), where Silurian limestone is covered by glacial and marine deposits. A $13.5 \mathrm{~km}$ long, north-south orientated esker ridge at 8-10 $\mathrm{m}$ a.s.l. is situated $500 \mathrm{~m}$ east of the lake. The lake itself is surrounded by a small forested mire, and the threshold lies at $6.8 \mathrm{~m}$ a.s.l. in the southwestern part. The base of the highest levelled beach ridge is at $10 \mathrm{~m}$ a.s.l. (Ratas, 1976). The core was taken from the overgrown eastern part of the lake (58 $\left.43^{\prime} 44^{\prime \prime} \mathrm{N}, 22^{\circ} 37^{\prime} 02^{\prime \prime} \mathrm{E}\right)$. The nearest locality dated by the ESR method is the Muda Quarry, 4 km north of Prassi (Fig. 1B). It exposes sand rich in mollusc shells, at ca. 8-9 $\mathrm{m}$ a.s.l., where the bivalve Cerastoterma glaucum was dated to $2700 \mathrm{yr}$ BP (Molodkov and Raukas, 1996).

\section{METHODS}

A series of overlapping $(0.2-0.5 \mathrm{~m})$ cores were obtained with a Russian peat sampler from the Loopsoo, Tihu and Prassi basins in summer 2012 and from Kõivasoo in summer 1999 
(Table 1). One metre long core sections were described in the field, photographed, sealed in plastic liners and transported to the laboratory. Loss-on-ignition (LOI), grain-size, magnetic susceptibility (MS), radiocarbon dates and diatom analyses were carried out on the sediments. Organic matter (OM) was examined continuously from $1 \mathrm{~cm}$ thick samples ignited at $525^{\circ} \mathrm{C}$ for 4 hours, and the results are expressed in percentages of dry matter. The percentage of carbonates $\left(\mathrm{CaCO}_{3}\right)$ was calculated after combustion of LOI residue for 2 hours at $900^{\circ} \mathrm{C}$. The amount of residue was described as mineral matter and calculated from the sum of organic and carbonate compounds. Volume specific MS K, expressed in SI units, was measured with a Bartington Instruments $M S 2 E$ scanning sensor at $1 \mathrm{~cm}$ resolution from the carefully cleaned sediment surface. Sediment grain size was measured by a Horiba laser scattering particle size analyser from the mineral portion of sediment with the interval of $2.5-5.0 \mathrm{~cm}$. Organic matter was removed by wet oxidation with $30 \%$ hydrogen peroxide and carbonates by $10 \%$ $\mathrm{HCl}$, and the grain-size classification follows the Udden-Wentworth scale (Last, 2001).

Diatom preparation followed techniques outlined in Battarbee (2001). Diatom samples were digested in hydrogen peroxide and permanently mounted onto microscope slides using Naphrax medium. Usually, about 400 diatom valves were counted in each sample and identified to the species level in order to estimate the percentage abundance of each taxon. In some sandy samples, diatom preservation was poor, but nonetheless, a minimum of 100 identifiable diatoms were counted. Diatoms were grouped according to their living habitat into planktonic, small-sized fragilarioid and periphytic taxa, and with regard to their salinity tolerance into marine/brackish, halophilous, small-sized fragilarioid taxa with brackish-water affinity, small-sized fragilarioid taxa, indifferent, freshwater and unidentified taxa. Diatom floras, used for the identification and ecological information, were derived from different sour- ces (Krammer and Lange-Bertalot, 1986, 1988, 1991a, b; Snoeijs, 1993; Snoeijs and Vilbaste, 1994; Snoeijs and Potapova, 1995; Snoeijs and Kasperovičienè, 1996; Snoeijs and Balashova, 1998).

The age-depth control of sediment sequences was provided from peat, gyttja and plant macrofossils (Table 2). Four dates from charcoal particles, collected by archaeologists from the settlement sites near Kõivasoo, were also considered in the water level curve reconstruction. The material for dating was picked up based on the lithological boundaries, and prioritizing the discovery of terrestrial macrofossils. Macrofossils were extracted by soaking 1 or $5 \mathrm{~cm}$ thick samples in water and $\mathrm{Na}_{4} \mathrm{P}_{2} \mathrm{O}_{7}$ solution, and by wet sieving the material through a $0.20 \mathrm{~mm}$ mesh. Obtained terrestrial material was dried at $70^{\circ} \mathrm{C}$ and dated in the Poznań Radiocarbon Laboratory. The radiocarbon ages were calibrated to calendar years (cal yr BP, $0=$ $1950)$ at $95.4 \%$ probability range using the IntCal13 calibration dataset (Reimer et al., 2013) and the OxCal 4.2 program (Bronk Ramsey, 2009). Radiocarbon dates were combined with lithological data using the OxCal deposition model (Bronk Ramsey, 2008), and weighted average ages were used in the current study (Table 2). Two radiocarbon dates from Loopsoo: $1240 \pm$ $30 \mathrm{yr}$ BP (Poz-50760) and $5140 \pm 40 \mathrm{yr} \mathrm{BP}$ (Poz-50763), and two dates from Tihu: $1120 \pm 40 \mathrm{yr}$ BP (Poz-50761) and $2960 \pm$ $100 \mathrm{yr}$ BP (Poz-52922) (Table 2) are too young and have not been considered in the age-depth model. Diatom and LOI results were plotted using the TGView software (Grimm, 2011).

Lithological (Table 1 and Fig. 2), biostratigraphical (Fig. 3) and geochronological proxies (Table 2) of the current and earlier studies (Kents, 1939; Sepp, 1974; Sarv et al., 1982; Raukas et al., 1992, 1996; Molodkov and Raukas, 1996; Königsson et al., 1998; Saarse et al., 2000, 2009) and GIS-based water level surfaces (Saarse et al., 2003, 2006) were used to reconstruct shore displacement curves for Hiiumaa Island. The GIS-based water level surfaces are presented with \pm 1 metre error bars for

Sediment description of studied sites

\begin{tabular}{|c|c|c|c|}
\hline Site name and altitude & Position of coring site & Depth [cm] & Sediment description \\
\hline $\begin{array}{l}\text { Kõivasoo, } \\
27.5 \text { m a.s.I. }\end{array}$ & $\begin{array}{l}58^{\circ} 54^{\prime} 32^{\prime \prime}, \mathrm{N}, \\
22^{\circ} 11^{\prime} 56^{\prime} \mathrm{E}\end{array}$ & $\begin{array}{c}0-197 \\
197-240 \\
240-265 \\
265-318 \\
318-325 \\
325-351\end{array}$ & $\begin{array}{c}\text { peat } \\
\text { coarse detritus gyttja } \\
\text { calcareous silt with plant remains } \\
\text { calcareous silt with mollusc shells } \\
\text { silt with mollusc shells } \\
\text { fine-grained sand with mollusc shells }\end{array}$ \\
\hline $\begin{array}{l}\text { Loopsoo, } \\
21.5-22 \mathrm{~m} \text { a.s.I. }\end{array}$ & $\begin{array}{l}58^{\circ} 53^{\prime} 41^{\prime \prime} \mathrm{N}, \\
22^{\circ} 40^{\prime} 21^{\prime \prime} \mathrm{E}\end{array}$ & $\begin{array}{c}0-290 \\
290-350 \\
350-371 \\
371-395 \\
395-443 \\
443-468\end{array}$ & $\begin{array}{c}\text { Sphagnum peat, brown } \\
\text { transitional peat, dark brown } \\
\text { fen peat, light brown } \\
\text { minerogenic gyttja } \\
\text { sandy silt with organic matter, grey } \\
\text { sand }\end{array}$ \\
\hline $\begin{array}{l}\text { Tihu Keskjärv, } \\
14.5 \text { m a.s.l. }\end{array}$ & $\begin{array}{l}58^{\circ} 51^{\prime} 48^{\prime \prime} \mathrm{N}, \\
22^{\circ} 32^{\prime} 24^{\prime \prime} \mathrm{E}\end{array}$ & $\begin{array}{c}0-140 \\
140-191 \\
191-204 \\
204-206 \\
206-225\end{array}$ & $\begin{array}{c}\text { peat, well-decomposed, brown } \\
\text { coarse detritus gyttja, dark brown } \\
\text { sand, greyish brown } \\
\text { sand with gravel and pebbles, dark grey } \\
\text { silty clay with clasts (till?), bluish-grey }\end{array}$ \\
\hline $\begin{array}{l}\text { Prassi, } \\
7.5 \mathrm{~m} \text { a.s.I. }\end{array}$ & $\begin{array}{l}58^{\circ} 43^{\prime} 44^{\prime \prime} \mathrm{N}, \\
22^{\circ} 37^{\prime} 02^{\prime \prime} \mathrm{E}\end{array}$ & $\begin{array}{c}0-110 \\
110-117 \\
117-174 \\
174-176 \\
176-200 \\
200-225\end{array}$ & $\begin{array}{l}\text { reed peat, brown } \\
\text { sandy peat } \\
\text { sand, fine-grained, grey } \\
\text { gravel, brownish-grey } \\
\text { clay, bluish-grey } \\
\text { clay, beige }\end{array}$ \\
\hline
\end{tabular}


Radiocarbon dates calibrated at $95.4 \%$ probability from the Hiiumaa Island sequences

\begin{tabular}{|c|c|c|c|c|c|c|}
\hline Site name & $\begin{array}{c}\text { Depth, } \\
\text { cm/elevation [m a.s.I.] }\end{array}$ & $\begin{array}{c}{ }^{14} \mathrm{C} \text { date } \\
{[\mathrm{BP}]}\end{array}$ & $\begin{array}{l}\text { Calibrated age, BP } \\
\text { (weighted average) }\end{array}$ & $\begin{array}{c}\text { Laboratory } \\
\text { no }\end{array}$ & Dated material & Reference \\
\hline Kõivasoo & $213-223$ & $6580 \pm 60$ & $\begin{array}{l}7430-7580 \\
(7510 \pm 50) \\
\end{array}$ & TA-527 & gyttja & Königsson et al. (1998) \\
\hline Kõivasoo & 245.5 & $6830 \pm 90$ & $\begin{array}{l}7750-8000 \\
(7890 \pm 60) \\
\end{array}$ & Ua-12071 & plant remains & Königsson et al. (1998) \\
\hline Kõivasoo & $245-255$ & $7440 \pm 60$ & $\begin{array}{l}8020-8250 \\
(8120 \pm 70) \\
\end{array}$ & TA-528 & carbonate fraction & Königsson et al. (1998) \\
\hline Kõivasoo & $260-270$ & $7850 \pm 70$ & $\begin{array}{l}8410-8610 \\
(8490 \pm 50) \\
\end{array}$ & TA-529 & carbonate fraction & Königsson et al. (1998) \\
\hline Kõivasoo & $315-325$ & $8190 \pm 90$ & $\begin{array}{l}9170-9490 \\
(9350 \pm 90) \\
\end{array}$ & TA-530 & carbonate fraction & Königsson et al. (1998) \\
\hline Loopsoo & $365-366$ & $5190 \pm 40$ & $\begin{array}{l}5430-5570 \\
(5490 \pm 40) \\
\end{array}$ & Poz-52916 & peat & current study \\
\hline Loopsoo & $370-371$ & $5050 \pm 40$ & $\begin{array}{l}5450-5570 \\
(5520 \pm 30) \\
\end{array}$ & Poz-52917 & peat & current study \\
\hline Loopsoo & $377-382$ & $5600 \pm 40$ & $\begin{array}{l}5890-6100 \\
(5980 \pm 60)\end{array}$ & Poz-52918 & plant remains & current study \\
\hline Loopsoo* & 419 & $1240 \pm 30$ & $\begin{array}{l}1070-1270 \\
(1180 \pm 60) \\
\end{array}$ & Poz-50760 & wood (root?) & currtent study \\
\hline Loopsoo* & $450-455$ & $5140 \pm 40$ & $\begin{array}{l}5750-5990 \\
(5670 \pm 70)\end{array}$ & Poz-50763 & plant remains & current study \\
\hline Tihu & 186 & $4470 \pm 40$ & $\begin{array}{l}4900-5270 \\
(5080 \pm 90)\end{array}$ & Poz-52920 & twig & current study \\
\hline Tihu $^{*}$ & $190-195$ & $1120 \pm 40$ & $\begin{array}{c}940-1170 \\
(1030 \pm 60)\end{array}$ & Poz-50761 & bark & current study \\
\hline Tihu & $200-204$ & $4490 \pm 40$ & $\begin{array}{l}5050-5300 \\
(5200 \pm 70) \\
\end{array}$ & Poz-52921 & plant remains & current study \\
\hline Tihu* $^{*}$ & $210-215$ & $2960 \pm 100$ & $\begin{array}{c}2870-3370 \\
(3120 \pm 130)\end{array}$ & Poz-52922 & plant remains & current study \\
\hline Prassi & 110 & $1020 \pm 30$ & $\begin{array}{l}830-1050 \\
(940 \pm 30)\end{array}$ & Poz-52915 & plant remains & current study \\
\hline Prassi & 114 & $1550 \pm 30$ & $\begin{array}{l}1310-1430 \\
(1370 \pm 30)\end{array}$ & Poz-50758 & wood & current study \\
\hline Prassi & 123 & $1480 \pm 40$ & $\begin{array}{l}1350-1510 \\
(1410 \pm 50) \\
\end{array}$ & Poz-50759 & bark & current study \\
\hline Prassi & 139 & $1490 \pm 30$ & $\begin{array}{l}1360-1520 \\
(1420 \pm 50) \\
\end{array}$ & Poz-52914 & wood & current study \\
\hline Prassi & 189 & $1630 \pm 30$ & $\begin{array}{l}1420-1600 \\
(1520 \pm 50) \\
\end{array}$ & Poz-52913 & wood & current study \\
\hline Pihla Bog & $\begin{array}{c}505-515 / \\
14 \text { m a.s.l. }\end{array}$ & $3280 \pm 180$ & $\begin{array}{c}3040-3990 \\
(3530 \pm 230) \\
\end{array}$ & TA-29 & woody peat & Liiva et al. (1966) \\
\hline Kõpu I & $26.5 \mathrm{~m}$ a.s.l. & $5700 \pm 70$ & $\begin{array}{l}6320-6660 \\
(6500 \pm 80) \\
\end{array}$ & TIn-1901 & charcoal & Kriiska and Lõugas (1999) \\
\hline Kõpu I & $26.5 \mathrm{~m}$ a.s.l. & $5330 \pm 90$ & $\begin{array}{c}5930-6290 \\
(6110 \pm 110) \\
\end{array}$ & TA-1493 & charcoal & Kriiska and Lõugas (1999) \\
\hline Kõpu IV & $28 \mathrm{~m}$ a.s.l. & $6760 \pm 50$ & $\begin{array}{l}7520-7680 \\
(7620 \pm 40) \\
\end{array}$ & TIn-2016 & charcoal & Kriiska and Lõugas (1999) \\
\hline Kõpu IV & $28 \mathrm{~m}$ a.s.l. & $6640 \pm 60$ & $\begin{array}{r}7430-7610 \\
(7520 \pm 50) \\
\end{array}$ & TA-2533 & charcoal & Kriiska and Lõugas (1999) \\
\hline Kõpu VIII & $28 \mathrm{~m}$ a.s.l. & $6170 \pm 50$ & $\begin{array}{l}6940-7240 \\
(7070 \pm 70) \\
\end{array}$ & Tln-2024 & hazelnut shells & Kriiska and Lõugas (1999) \\
\hline
\end{tabular}

Dates marked by asterisk have not been considered in the age-depth model

Kõivasoo and Prassi, but not for Loopsoo and Tihu, to keep Figure 4 readable. Timing and changes in the water level at Kõivasoo is based on Saarse et al. (2000), and that of Prassi follows the bio- and chronostratigraphical evidence from the Vääna lagoon in northern Estonia (Saarse et al., 2009), locating at the same Litorina Sea isobase as Prassi.
The GIS-based palaeogeographic maps were created by removing interpolated water level surfaces and thickness of peat deposits from the digital terrain model (DTM; Rosentau et al., 2009). A $10 \times 10 \mathrm{~m}$ grid-size DTM was used for the current study. The land area is based on the Light Detection And Ranging data (LIDAR) from the Estonian Land Survey. For the off- 


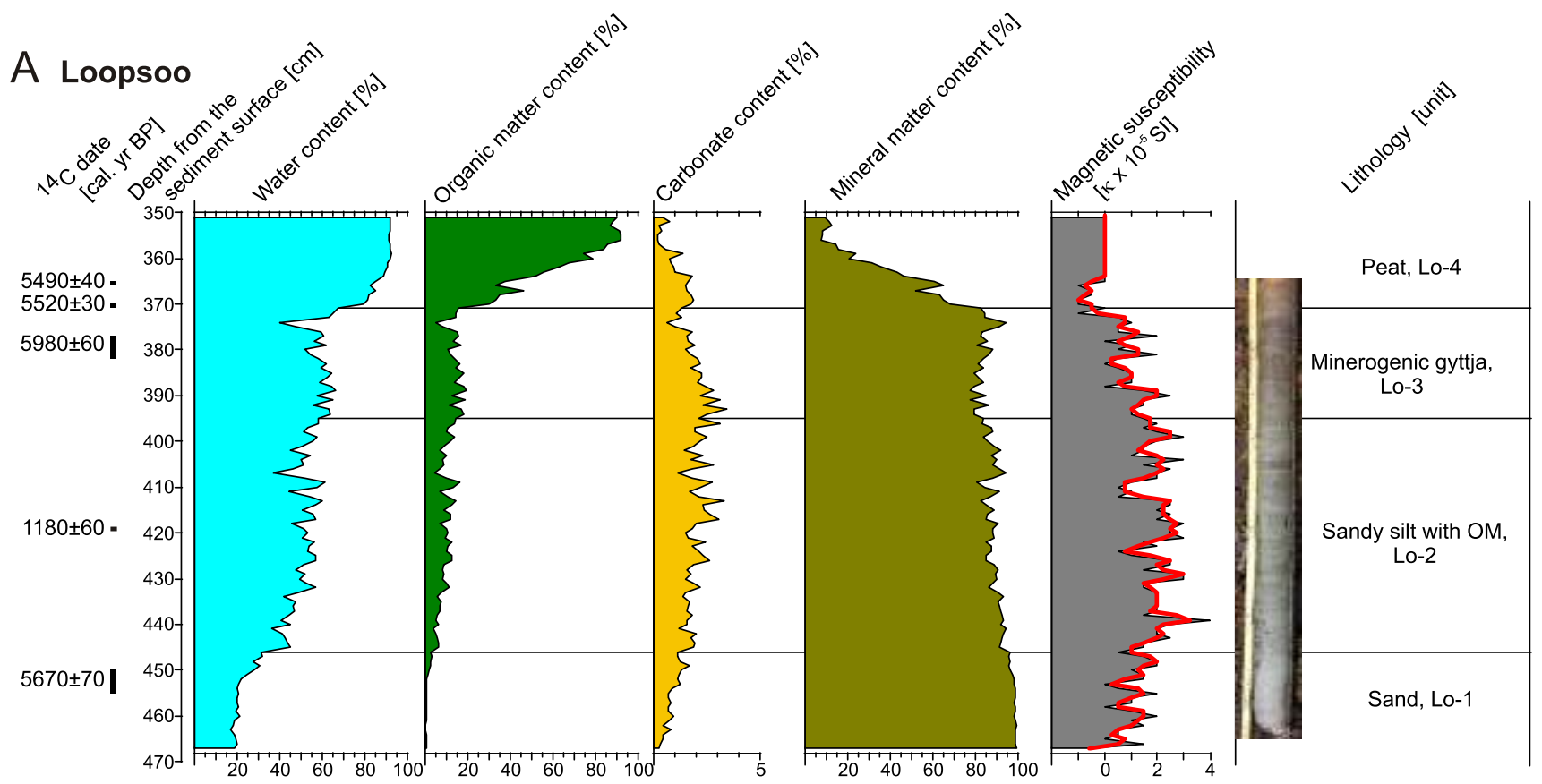

B Tihu

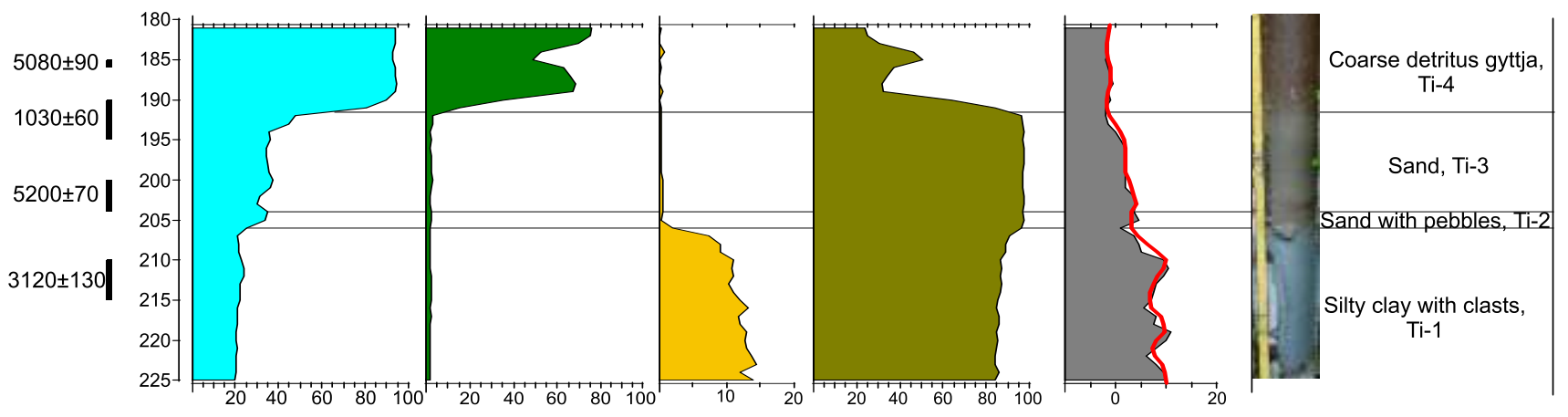

C Prassi

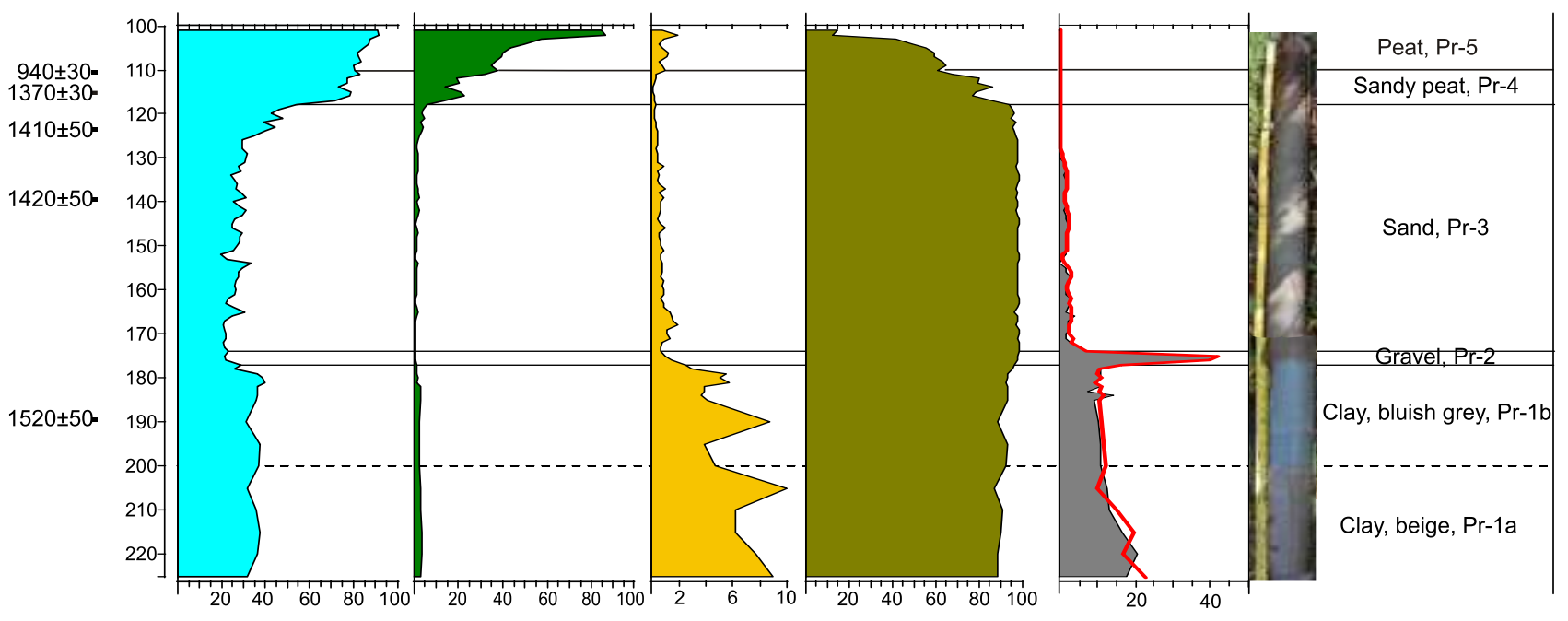

Fig. 2. Loss-on-ignition, magnetic susceptibility results and the lithological units of Loopsoo (A), Tihu (B) and Prassi (C) 


\section{A Kõivasoo}
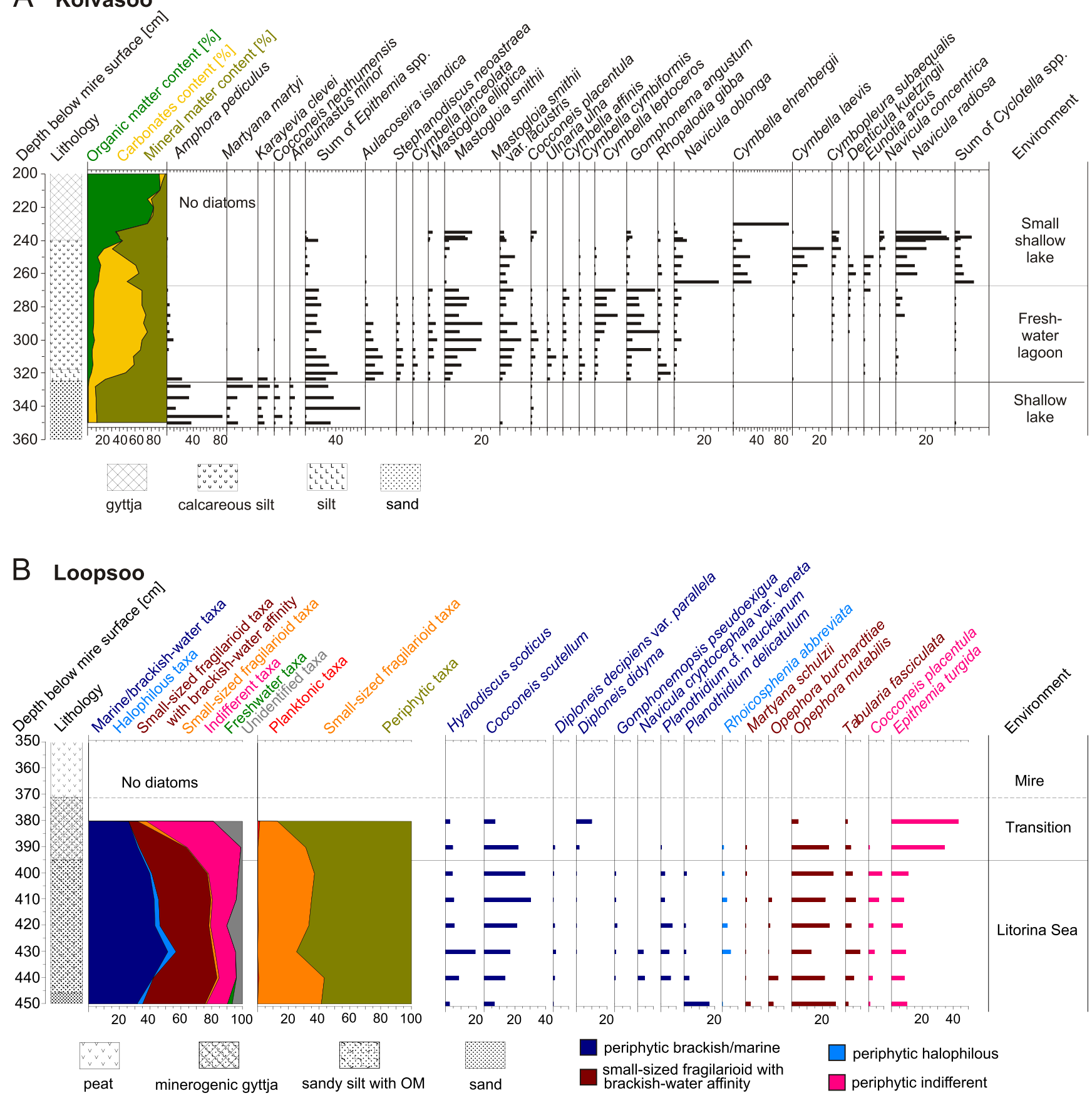

shore area, 1:10,000, 1:25,000 and 1:50,000 scale topographic maps were used. The peat deposits were removed from the DTM according to the1:10,000 scale soil maps (Estonian Land Survey) and unpublished reports from the Estonian Geological Survey. GIS-based water level surfaces for the Ancylus Lake $(10,300$ cal. yr BP) and the Litorina Sea (7800 cal. yr BP) were derived from the Estonian coastal formation database (Saarse et al., 2003, 2006). The water level surfaces were created with \pm 1 metre residual, so that the reconstructed mean water level can fluctuate about 2 metres. In the current paper, the Litorina Sea water level surface (7800 cal. yr BP) was modified according to the assumption that the relative sea level has regressed
Fig. 3. Diatom diagrams of the Kõivasoo (A), Loopsoo (B),

evenly due to a linear land uplift (Mörner, 1979; Lindén et al., 2006) and new water level surfaces for $8500,7100,6800,5100$, 4800, 4400, 2700 and 2200 cal. yr BP were interpolated.

\section{RESULTS}

The Kõivasoo sequence (Table 1, Figs. 1B and 3A) contains fine-grained sand with mollusc shell fragments $(325-351 \mathrm{~cm})$, silt with mollusc shells $(318-325 \mathrm{~cm})$, calcareous silt with mollusc shells $(265-318 \mathrm{~cm})$, calcareous silt with 

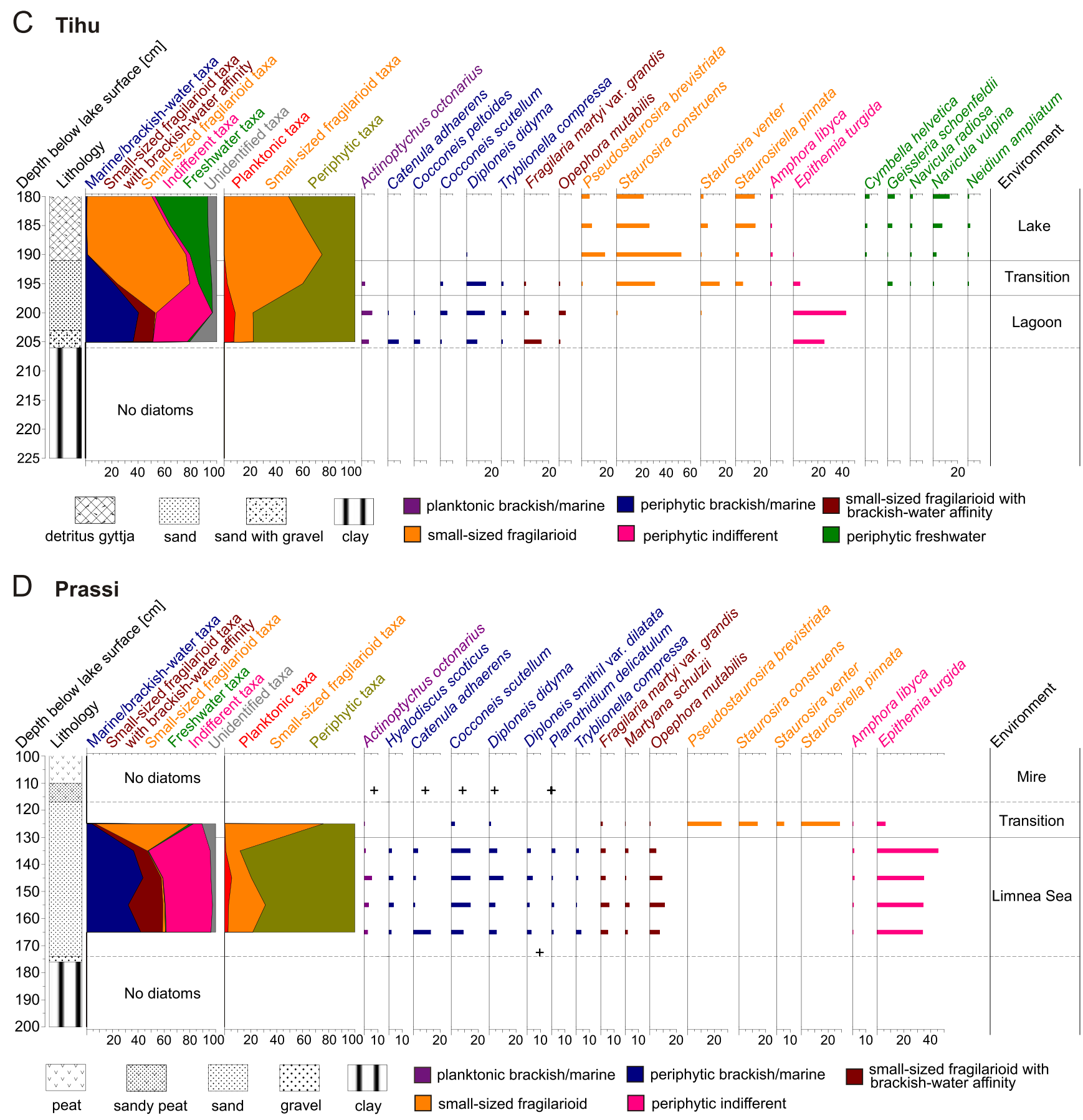

Tihu (C) and Prassi (D) sites

plant remains and mollusc shells $(240-265 \mathrm{~cm})$, coarse detritus gyttja $(197-240 \mathrm{~cm}$ ) and peat from $197 \mathrm{~cm}$ upwards (Sarv et al., 1982; Saarse et al., 2000; Table 1). Unlike the other studied sites, silt is highly calcareous and contains over $50 \%$ of carbonates. The boundary between calcareous silt and coarse detritus gyttja is richly paved with mollusc shells.

The diatom flora in the basal part of the Kõivasoo sequence (Fig. 3A) consists of freshwater taxa typical of shallow coastal lake, including Amphora pediculus, Martyana martyi, Karayevia clevei, Cocconeis neothumensis and Epithemia spp., which inhabit mostly littoral areas of hard-water lakes. Planktonic and large-lake taxa are absent. A change from shallow-lake taxa to planktonic large-lake taxa, such as Aulacoseira islandica, Stephanodiscus neoastraea and littoral Mastogloia spp. (Masto- gloia elliptica, M. smithii and M. smithii var. lacustris) at a depth of $325 \mathrm{~cm}$ refers to the Early Litorina Sea sub-stage and the formation of a freshwater lagoon. Between core depths of 230 and $265 \mathrm{~cm}$, large-lake diatoms disappear and the proportion of Mastogloia taxa decreases, being replaced by Cymbella ehrenbergii, C. laevis, Navicula radiosa and other shallow-water small-lake taxa.

The Loopsoo section includes four units: sand, laminated sandy silt with dispersed OM, minerogenic gyttja, and peat (Table 1 and Fig. 2A). The fine-grained sand layer (Lo-1; $446-468 \mathrm{~cm}$ ) includes $89-96 \%$ of sand, $4-11 \%$ of silt and very few OM (Fig. 2A). It is overlain by distinctly bedded sandy silt with dispersed OM (Lo-2; 395-446 cm), containing 53-72\% of silt and $28-47 \%$ of sand. The content of OM, carbonates and 


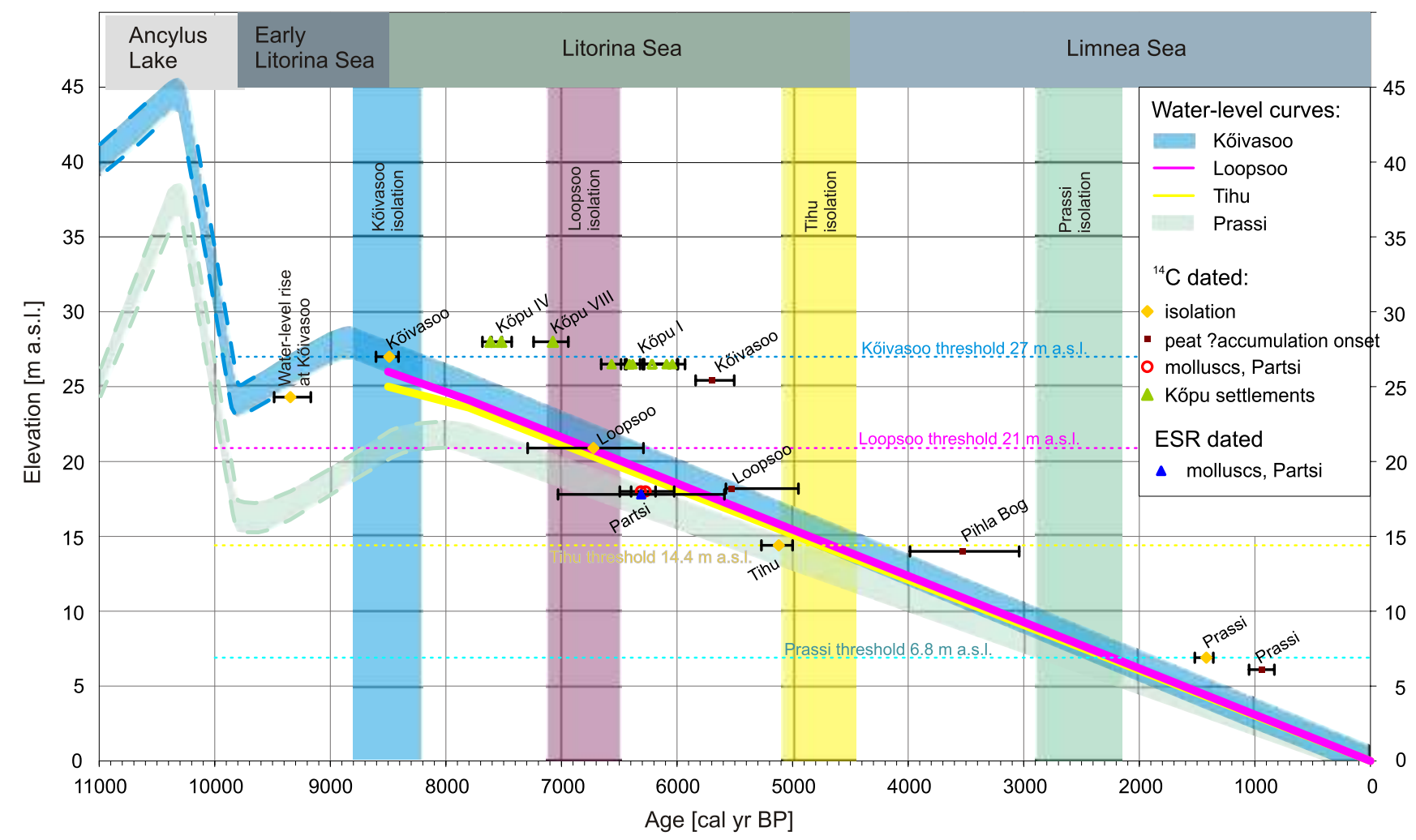

Fig. 4. Water-level curves for the Hiiumaa region, based on different proxies

mineral matter is variable, depending on sediment structure, but still fluctuating in a small range. In minerogenic gyttja (unit Lo-3; $371-395 \mathrm{~cm}$ ), the OM content slightly rises to $18 \%$, however, the mineral component is still as high as $77-94 \%$ (Fig. $2 A)$, of which sand fraction covers $38-53 \%$ and silt $47-62 \%$. A major shift in LOI results occurs at $371 \mathrm{~cm}$, where the OM content rapidly increases marking the onset of peat deposition at about $5520 \pm 40$ cal yr BP (Table 2 and Fig. 2A). The carbonate content remains low throughout the sequence (less $5 \%$ ), as does MS, fluctuating between $0-4 \times 10^{-5} \mathrm{SI}$ (Fig. 2A).

The diatom composition in the Loopsoo sequence indicates two types of environment, the Litorina Sea and pre-isolation transitional phase (Fig. 3B). Marine/brackish-water and smallsized fragilarioid taxa with brackish-water affinity dominate in the basal sequence to a depth of $395 \mathrm{~cm}$. The sandy layer from the bottom part reveals the highest peak of epipsammic marine/brackish-water Planothidium delicatulum (17\%) and small-sized fragilarioid Opephora mutabilis (29\%), indicating a brackish-water environment. Epiphytic diatoms, such as marine/brackish-water Hyalodiscus scoticus, Cocconeis scutellum, Gomphonemopsis pseudoexigua, Tabularia fasciculata and halophilous Rhoicosphenia abbreviata, which are typically found in the Baltic Sea (Witkowski, 1994; Snoeijs and Balashova, 1998; Witkowski et al., 2000) together with epipsammic diatoms (Planothidium cf. hauckianum, Opephora burchardtiae and $O$. mutabilis), comprise about $75 \%$ of all identified diatoms. At a core depth of $395 \mathrm{~cm}$, where sandy silt is replaced by minerogenic gyttja, indifferent epiphytic Epithemia turgida prevails over marine/brackish-water and small-sized fragilarioid taxa with brackish-water affinity, marking the beginning of the transition zone.

The Tihu sequence consists of four lithological units (Table 1 and Fig. 2B): bluish-grey silty clay with clasts resembling waterlain till (Ti-1, 206-225 cm), sand with gravel and pebbles typical of erosional surfaces (Ti-2, 204-206 cm), sand (Ti-3,
191-204 cm), and coarse detritus gyttja (Ti-4, 140-191 cm). The OM content in basal silty clay is $1-2 \%$, the carbonate content fluctuates between $9-14 \%$, mineral matter is up to $91 \%$, and MS up to $10 \times 10^{-5} \mathrm{SI}$ (Fig. 2B). Mineral matter is dominated by the clay fraction, accounting for $40-51 \%$. The silt and sand contents vary between $39-46 \%$ and $10-14 \%$, respectively. In addition, this sediment section contains sparse gravel grains and pebbles. Macrofossils from a core depth of $210-215 \mathrm{~cm}$ are dated to $3120 \pm 130 \mathrm{cal} \mathrm{yr} \mathrm{BP}$ (Table 2), which is not consistent with both the uppermost date and the suggestion that this sediment is waterlain till.

The erosional bed at 204-206 cm (Ti-2) consists of sand with gravel and pebbles, cemented sandstone nodules and broken mollusc shells. Its LOI results are similar to those of the overlying sand (Fig. 2B). Sand (Ti-3; 191-204 cm) is fine to very fine in grain size with the OM content less than $3 \%$, carbonates $0.2-0.6 \%$, and mineral matter up to $97 \%$. The MS values are low and range between $1-4 \times 10^{-5} \mathrm{SI}$ (Fig. 2B). According to grain size distribution, the sand fraction content fluctuates between $78-94 \%$, and silt between 6-29\%, whereas clay fraction is absent. Deposition of this sediment started about $5200 \pm$ 70 cal yr BP. At $191 \mathrm{~cm}$ (Ti-4), sand is replaced by coarse detritus gyttja. The content of OM increases to $76 \%$, and the content of mineral matter decreases to $24 \%$ (Fig. 2B). The AMS date from bark at the isolation contact $(190-195 \mathrm{~cm})$ shows an age of $1030 \pm 60$ cal yr BP (Table 2) and probably represents a macrofossil remain that is swept downwards during coring. If the radiocarbon dates from coarse detritus gyttja and the basal part of sand are correct (Table 2), then the $12 \mathrm{~cm}$ thick sand (unit Ti-3) was deposited during a period of 60-200 years.

No diatoms have been found in unit Ti-1 (Fig. 3C), supporting the interpretation that the unit represents waterlain till. The first remnants of broken diatom frustules were observed in the sandy and gravelly unit Ti-2 at a depth of $205 \mathrm{~cm}$. As the preservation of diatoms in this layer was poor, broken parts of marine/brack- 
ish-water planktonic Actinoptychus octonarius, epipelic Diploneis didyma and indifferent epiphytic Epithemia turgida, and smallsized diatoms resistant to erosion, such as Fragilaria martyi var. grandis and Catenula adhaerens, have been identified. The dominance of marine/brackish-water planktonic Actinoptychus octonarius (8\%), epiphytic Cocconeis scutellum (5\%), epipelic Diploneis didyma (15\%) and Tryblionella compressa, and indifferent epiphytic Epithemia turgida (43\%) at a depth of $197-205 \mathrm{~cm}$, i.e. representing unit Ti-2 and the lower part of unit $\mathrm{Ti}-3$, indicate a brackish-water environment and most likely a pre-isolation lagoonal phase of the basin. The short-lived transition stage is characterized by mass occurrence of small-sized fragilarioid taxa such as Staurosira construens (up to $50 \%$ ), S. venter (15\%) and Staurosirella pinnata, decreased abundance of marine/brackish-water and indifferent taxa, and appearance of freshwater periphytic diatoms like Geissleria schoenfeldii, Navicula vulpina, Neidium ampliatum etc.

The lithology of Prassi (Table 1 and Fig. 2C) is similar to that of Tihu. The basal clay unit is subdivided into beige ( $\mathrm{Pr}-1 \mathrm{a}$, 200-225 cm) and bluish-grey (Pr-1b, 176-200 cm) clayey subunits covered by a thin gravel bed $(\operatorname{Pr}-2,174-176 \mathrm{~cm})$, sand (Pr-3; 117-174 cm) and sandy peat (Pr-4, 110-117 cm) that gradually turns upwards to peat (Table 1 and Fig. $2 \mathrm{C}$ ). The OM content of basal clay remains between $1.4-3.8 \%$, but carbonates reach $10 \%$. The grain size of differently coloured clay is quite similar and composed mostly of clay (67-89\%) and silt (11-27\%) fraction, with subordinate sand fraction. A woody piece found at a core depth of $189 \mathrm{~cm}$ was AMS-dated to 1520 \pm 50 cal yr BP (Table 2). The overlying gravel (Pr-2) is poor in $\mathrm{OM}$ and carbonates but rich in magnetic minerals, up to $400 \times$ $10^{-5} \mathrm{SI}$ (Fig. 2C). Sand (Pr-3) contains a very low amount of $\mathrm{OM}$, carbonates and magnetic minerals (Fig. $2 \mathrm{C}$ ). Its grain size distribution is quite stable, with $75-87 \%$ of sand fraction and $13-25 \%$ of silt fraction. In sandy peat (Pr-4), at a depth of $100 \mathrm{~cm}$, the OM content increases to $85 \%$.

The basal clay, gravel and sand do not contain any diatom valves to a depth of $165 \mathrm{~cm}$ (Fig. 3D). The upper part of the sequence $(110-117 \mathrm{~cm})$ is also barren of diatoms. Diatom frustules have been identified and counted in the interval $120-165 \mathrm{~cm}$. Like in the Loopsoo sequence, the diatom assemblage of the Prassi sequence is dominated by epiphytic marine/brackish Hyalodiscus scoticus and Cocconeis scutellum (14\%), indifferent Epithemia turgida (35-46\%) and marine/brackish-water epipsammic Catenula adhaerens (13\%), Fragilaria martyi var. grandis (6\%), Martyana schulzii, Opephora mutabilis (11\%), all characteristic of the brackish shallow coastal waters (Witkowski, 1994). Abundance of marine/brackish-water planktonic Actinoptychus octonarius indicates that the Prassi Basin was a shallow, open bay of the Limnea Sea. The sharp change of diatom assemblages from marine/brackish-water and indifferent taxa to small-sized fragilarioid taxa (Pseudostaurosira brevistriata, Staurosira construens, S. venter and Staurosirella pinnata) that prefer freshwater conditions, marks the onset of the transition phase at $130-135 \mathrm{~cm}$ and the onset of isolation from the BSB.

\section{DISCUSSION}

\section{LITHO-, BIO- AND CHRONOSTRATIGRAPHY}

Basal sand $(325-351 \mathrm{~cm})$ from Kõivasoo contains mostly periphytic epipsammic (taxa attached to sand and silt grains) freshwater diatoms (e.g., Amphora pediculus) and indifferent
Epithemia spp. (Fig. 3A) inhabiting the bottom of shallow hardwater lakes in Estonia. Such a diatom assemblage refers to a low water level and an isolated shallow lake environment before 9400 cal yr BP. The water level dropped below the Kõivasoo threshold. Its exact level at that time is unknown, as it was filled with sand during the later transgression. Changes in the lithology at $325 \mathrm{~cm}$ (Table 1), a sharp decrease in Pediastrum (Königsson et al., 1998), and the appearance of large-lake planktonic diatoms (Fig. 3A) and molluscs, preferring deeper water environments (Kessel and Raukas, 1967), suggest that the Kõivasoo Basin was connected with the BSB $9350 \pm 90 \mathrm{cal}$ yr BP (Table 2), and the water level was higher than $24.3 \mathrm{~m}$ a.s.I. The diatom composition indicates that a freshwater lagoonal environment (Fig. 3A) with calcareous deposition $(325-265 \mathrm{~cm})$ lasted until ca $8490 \pm 50 \mathrm{cal} \mathrm{yr} \mathrm{BP}$ in Kõivasoo (Table 2). Disappearance of large-lake diatoms, decrease in Mastogloia spp. and replacement by taxa characteristic of small shallow lakes between core depths of 265 and $230 \mathrm{~cm}$ represent the final isolation of Kõivasoo from BSB.

The diatom flora shows that the sandy-silty beds in the Loopsoo Basin were deposited in the Litorina Sea. The presence of epipsammic (Planothidium delicatulum, $P$. cf. hauckianum, Martyana schulzii, Opephora mutabilis) and epiphytic (Hyalodiscus scoticus, Cocconeis scutellum, C. placentula) brackish-water diatoms indicates a shallow depositional environment (Fig. 3B). According to a shoreline displacement simulation, the water level near Loopsoo was at ca. $22 \mathrm{~m}$ a.s.I. by the onset of deposition of minerogenic gyttja (unit Lo-3), holding only ca. 1.5-2.0 m above the threshold elevation, and promoting erosion of the surrounding beach ridges and influx of sand to the Loopsoo Basin during the higher wave energy. The onset of isolation was most probably gradual and is recorded between 395 and $380 \mathrm{~cm}$ in the sediment section, which suggests that organic production increased prior to the final isolation of the basin (Lindén et al., 2006). According to the age-depth model, isolation started about $6720 \pm 270 \mathrm{cal}$ yr BP and terminated $5980 \pm 80$ cal yr BP, covering a transition period when marine/brackish-water diatoms still inhabited the basin (Fig. 3B). However, the long-lasting isolation is in conflict with water level simulation results, which show that isolation terminated about $6500 \mathrm{cal}$ yr BP. Such discrepancy could be explained by proximity of the Loopsoo Basin to the sea and location on a small island exposed to the winds and wave activity. Considering that the sedimentation of $24 \mathrm{~cm}$ thick minerogenic gyttja lasted 1200 years and the sedimentation rate was $0.2 \mathrm{~mm} \mathrm{yr}^{-1}$, a gap between gyttja and peat seems to be also realistic. In the upper part of minerogenic gyttja, where diatoms are absent, the sediment grain size turns more sandy due to shallowness of the basin and increased erosion.

The basal bluish-grey silty clay with clasts (unit Ti-1) in the Tihu sequence is most probably waterlain till widespread on Hiiumaa Island (Eltermann, 1993a, b; Kadastik and Kalm, 1998; Kalm and Kadastik, 2001; Kadastik, 2004). These deposits are also found in the bottom of Tihu Suurjärv (Saarse, unpubl.). The grain size distribution chart of waterlain till is multimodal and the contact with the overlying beds is sharp and paved with dropstone (Kadastik and Kalm, 1998). If the basal silty clay is waterlain till, there should be a long-lasting hiatus between sand and clay, as it deposited not later than 13,000 years ago (Saarse et al., 2012), and mid-Holocene sand during the Litorina Sea stage. However, it is difficult to explain why the older portion of the Litorina Sea sediment is absent. Location of studied core on the basin slope, accessible to erosion of stormy waves, could be a rationale. Sand with gravel and pebbles between clayey and sandy deposits indicate a water level lowering 
and erosion. A question arises, when such erosion took place. If that basal clay deposited during the Ancylus Lake, and considering that the Ancylus Lake maximum level at Tihu was $41 \mathrm{~m}$ a.s.I. and that the water level drop during the following regression was 30 m (Raukas and Ratas, 1996), the Tihu area should have been emerged, which would explain the erosion and hiatus. Thus, the basal silty clay with clasts represents most likely waterlain till.

During the Litorina Sea stage, typical marine diatoms (Catenula adhaerens, Diploneis didyma, Actinoptychus octonarius etc.) inhabited the basin (Fig. 3C). Dominance of epiphytic and epipsammic diatoms indicates that, Tihu, like Loopsoo, was a shallow overgrowning lagoon of the Litorina Sea at that time. However, unlike at Loopsoo and Prassi, the transition zone from a lagoon to a freshwater basin in Tihu is marked by a peak of small-sized fragilarioid taxa (Fig. 3C), indicating a change in depositional environment (Seppä and Tikkanen, 1998; Seppä et al., 2000; Risberg et al., 2005; Grudzinska et al., 2012, 2013). Sand replacement by coarse detritus gyttja marks the isolation contact at $191 \mathrm{~cm}$ and is in accordance with a change in diatom assemblage from marine/brackish-water taxa to freshwater taxa (Fig. 3C).

Similarly to the Tihu section, the sediment sequence of Prassi also includes lowermost clayey deposits covered by a thin gravel bed rich in magnetic minerals (Fig. 2C). The basal clay can be of glaciolacustrine origin (Eltermann, 1993a), as suggested by the absence of diatoms. However, the AMS radiocarbon date indicates a much younger age (Table 2) and refers to re-deposition of material and/or contamination during coring. The overlying gravel bed with a high content of magnetic minerals is interpreted as an erosional event. If the basal clay is re-deposited and the AMS date $1520 \pm 50 \mathrm{cal} \mathrm{yr} \mathrm{BP}$ is reliable, then the erosional surface was formed about $1440 \pm 50 \mathrm{cal} \mathrm{yr}$ BP. Marine/brackish-water diatoms, characteristic of the Limnea Sea, are preserved only in the middle part of sand (Fig. $3 \mathrm{D})$, whereas the lower and upper parts of sand were barren of diatoms. According to the diatom composition, the beginning of the transition from the Limnea Sea to a more or less isolated water body is recorded at a core depth of $135 \mathrm{~cm}$ (Fig. 3D), but the absence of diatoms in the upper part of the sequence makes determination of the exact isolation contact indistinct. According to ${ }^{14} \mathrm{C}$ dates, Prassi isolated about $1400 \mathrm{cal}$ yr BP, but this age is in conflict with the water level simulation results of the present study, which show that the isolation occurred about $2700 \mathrm{cal}$ yr BP. This age is concurrent with the ESR date from Cerastoterma glaucum of the Muda Quarry, $4 \mathrm{~km}$ north of Prassi (Molodkov and Raukas, 1996).

\section{RELATIVE SEA LEVEL CHANGES AND DEVELOPMENT} OF HIIUMAA

Relative sea level curves compiled for Kõivasoo, Loopsoo, Tihu and Prassi are presented in Figure 4. According to the GIS-based water level surfaces, derived from the Estonian coastal formation database (Saarse et al., 2003), the mean relative water level during the Ancylus Lake transgression about $10,300 \mathrm{cal}$ yr BP was $44.5 \mathrm{~m}$ a.s.I. at Kõivasoo, $41.6 \mathrm{~m}$ at Loopsoo, $40.9 \mathrm{~m}$ at Tihu, and $37.5 \mathrm{~m}$ at Prassi (Fig. 4). During the Litorina Sea transgression $7800 \mathrm{cal}$ yr BP, the mean water level was $24.9 \mathrm{~m}$ a.s.l. at Kõivasoo, $24.1 \mathrm{~m}$ at Loopsoo, $23.6 \mathrm{~m}$ at Tihu, and $21.5 \mathrm{~m}$ at Prassi. The reconstructed water level curve shows a linear decline since the Litorina Sea transgression, but it does not rule out minor changes being within error limits of simulation (Fig. 4). If large-scale water level fluctuations would have taken place between ca. 8000 cal yr BP (Kõivasoo) and ca. $1500 \mathrm{cal}$ yr BP (Prassi), they should have been visible in diatom stratigraphy and lithostratigraphy of the presently studied sections. The reconstructed water level curves display a diachronous Early Litorina/Litorina Sea transgression peak occurring earlier in the Kõivasoo area and later in the Prassi area as a result of the different rate of land uplift. The gradient of the highest Litorina Sea shoreline is ca $16.5 \mathrm{~cm} \mathrm{~km}^{-1}$ between Kõivasoo (at $27 \mathrm{~m}$ isobase) and Prassi (at $22 \mathrm{~m}$ isobase), and the distance between them is $30 \mathrm{~km}$. The calculated summary land uplift during the last 10,300 years was $4.4 \mathrm{~mm} \mathrm{yr}^{-1}$ at Kõivasoo, and has decreased to $2.5 \mathrm{~mm} \mathrm{yr}^{-1}$ at present (Torim, 2004). These results complement observations of recent investigations by Veski et al. (2005), Saarse et al. (2010), Grudzinska et al. (2013) and Rosentau et al. (2013).

The first island to emerge from the BSB about $11,000 \mathrm{cal} \mathrm{yr}$ BP was Kõpu, and the first shallow lake to isolate was Kõivasoo (Fig. 5). Kõpu Island, locating $80 \mathrm{~km}$ from mainland Estonia and containing abundant sand and gravel deposits, was long time subjected to strong winds and stormy waves that favoured the development of very mosaic topography as well as the Yoldia Sea/Ancylus Lake shoreline at 55-30 m a.s.l. (Kents, 1939) and the Early Litorina shoreline at 28-27 $\mathrm{m}$ a.s.I. The next island to emerge about $9000 \mathrm{cal}$ yr BP was a triangular outwash plane called Hiiu Island (Ratas, 1976). By 7800 cal yr BP, these two islands and three tiny islets were the only ones which formed the core of the present-day Hiiumaa (Fig. 6A). Despite the small size and distant location of Kõpu Island from the mainland, it was seasonally colonized by seal hunters between 7600 and $6100 \mathrm{cal}$ yr BP, as confirmed by artefacts and osteological material (Kriiska and Lõugas, 1999). During that time, Kõivasoo already existed as an isolated lake and provided freshwater for hunters enhancing their stay on the island. Shallowing and paludification of Kõivasoo Lake could be one of the reasons why their nearby settlements were abandoned. About $6100 \mathrm{cal}$ yr PB and about 5500 cal yr BP, Kõivasoo was fully overgrown by peat (Sarv et al., 1982).

Before the isolation, Loopsoo underwent a lagoonal (transitional) phase being strongly affected by the sea, as it was located on the small island in an open sea (Fig. 7A). Between

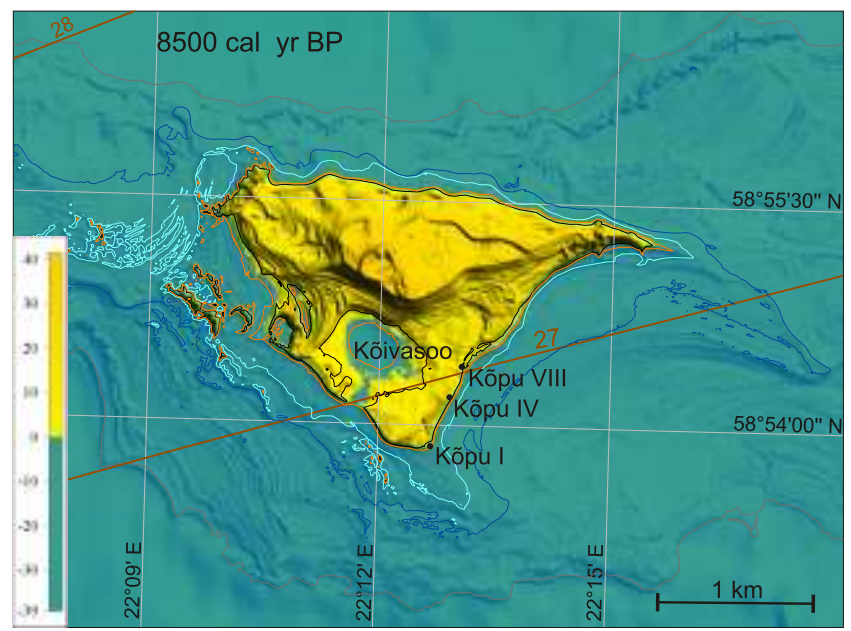

Fig. 5. 3D reconstruction at 8500 cal yr BP at Kõivasoo

Modelled water level surface isobases are indicated by brown lines together with elevations in metres a.s.l.; the shoreline is shown with a modelling error $\pm 1 \mathrm{~m}$ (black line $+1 \mathrm{~m}$, orange line $-1 \mathrm{~m}$ ); light blue line corresponds to the $5 \mathrm{~m}$ and blue to the $10 \mathrm{~m}$ water depth; black dots mark the location of archaeological sites 

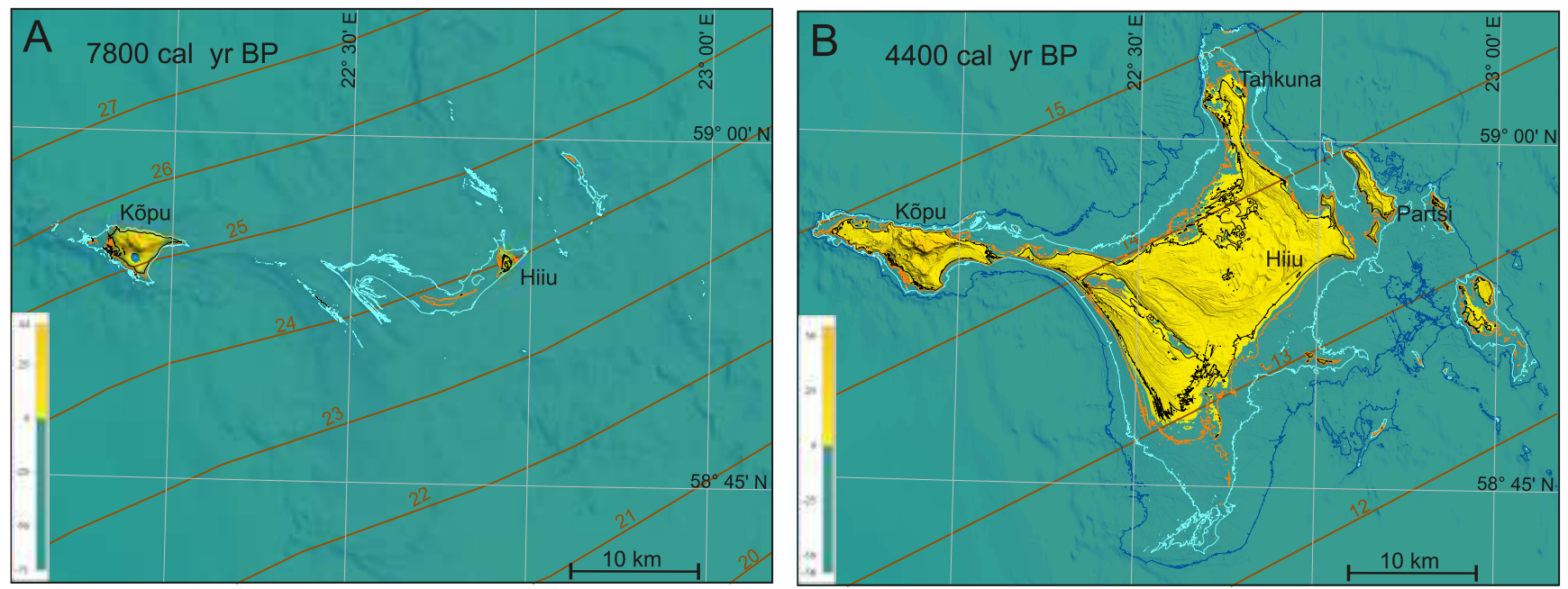

Fig. 6. 3D reconstructions of Hiiumaa Island at $7800 \mathrm{cal} \mathrm{yr} \mathrm{BP} \mathrm{(A)} \mathrm{and} 4400 \mathrm{cal}$ yr BP (B)

For explanations see Figure 5
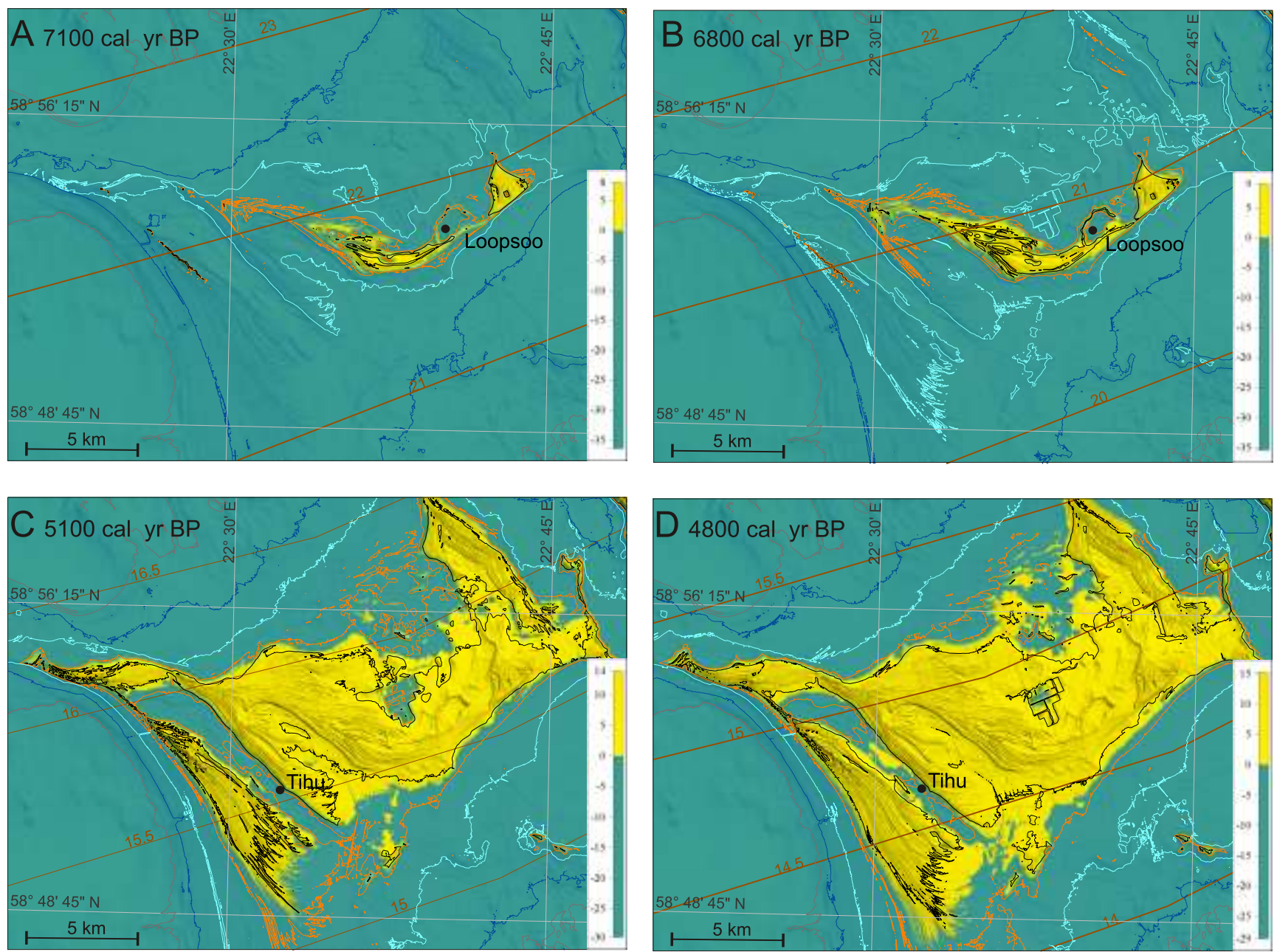

Fig. 7. 3D reconstructions at 7100 and $6800 \mathrm{cal}$ yr BP in the surroundings of Loopsoo (A, B) and at 5100 and $4800 \mathrm{cal} \mathrm{yr} \mathrm{BP}$ in the vicinity of Tihu (C, D)

For explanations see Figure 5 
7100 and $7000 \mathrm{cal}$ yr BP, sandy and shingle ridges surrounded Loopsoo Basin with narrow passage in north-east (Fig. 7A). It begun to isolate from the Litorina Sea most likely before 6800 cal yr BP, nevertheless, with storms and high wave activity, sea water flooded the basin during and after the isolation (Fig. 7B).

About 5100 cal yr BP, an elongated shallow lagoon existed in the Tihu depression with a passage to the sea in the southeast (Fig. 7C), which closed approximately 4800 cal yr BP. However, it seems likely that high waters were able to enter into the basin (Fig. 7D). Afterwards, the Tihu depression gradually transformed to land area where Tihu lakes remained as residual ones.

The youngest of the studied basin to isolate was Prassi. A shallow lagoon with a passage in the south occurred in the Prassi area about 2700 cal yr BP (Fig. 8A). A prolonged isolation process of the Prassi site was favoured by a flat topography, slightly inclined towards the west and south, a lack of barrier ridges, and exposure to the open sea (Fig. 8). Considering that the threshold elevation is at $6.8 \mathrm{~m}$ a.s.l., Prassi started to isolate about $2500 \mathrm{cal}$ yr BP, which is in conflict with radiocarbon dates (Table 2) that we discussed earlier. Furthermore, it is also possible that the uppermost part of sand with abundant woody pieces have been carried into the basin during heavy storms when the water level may rise up to $3 \mathrm{~m}$, as it was during the January storm in AD 2005.

It can conclude from the 3D reconstructions that Hiiumaa Island is relatively young in the present geographical shape. Its highest peak $68 \mathrm{~m}$ a.s.l. emerged from the BSB during the Yoldia Sea stage approximately 11,000 cal yr BP. Emerging BSB processes left behind erosional-prone sandy fields for waves and wind to create tiny islets, beach ridge systems, fan like bars, sandy terraces and spits forming now a very mosaic landscape. By $7800 \mathrm{cal}$ yr BP, only two large islands, Kõpu with an area of ca. $4 \mathrm{~km}^{2}$ and Hiiu ca. $1 \mathrm{~km}^{2}$, had been emerged (Fig. 6A). Due to a relatively fast land uplift by $4400 \mathrm{cal}$ yr BP, almost half of the present-day island was emerged from the sea (Fig. 6B).

\section{CONCLUSIONS}

1. Kõpu Peninsula, the highest part of Hiiumaa Island, started to emerge from the sea during the Yoldia Sea about $11,000 \mathrm{cal}$ yr BP and remained as an isolated island up to the onset of the Limnea Sea. The summary uplift rate since the emergence of Kõpu is $5.6 \mathrm{~mm} \mathrm{yr}^{-1}$ which has decreased to $2.5 \mathrm{~mm} \mathrm{yr}^{-1}$ at present.

2. According to the GIS-based water level simulation, the mean relative water level during the Ancylus Lake (about 10,300 cal yr BP) was $44.5 \mathrm{~m}$ a.s.l. at Kõivasoo, $41.6 \mathrm{~m}$ at Loopsoo, $40.9 \mathrm{~m}$ at Tihu, and $37.5 \mathrm{~m}$ at Prassi, and during the Litorina Sea (about 7800 cal yr BP) accordingly $24.9 \mathrm{~m}$ a.s.l. at Kõivasoo, $24.1 \mathrm{~m}$ at Loopsoo, $23.6 \mathrm{~m}$ at Tihu and $21.5 \mathrm{~m}$ at Prassi.

3. Diatom evidence indicates that, before $9400 \mathrm{cal}$ yr BP, the Kõivasoo Basin had existed as a small shallow lake. Afterwards, it was connected with the BSB, and a semi-closed fresh-
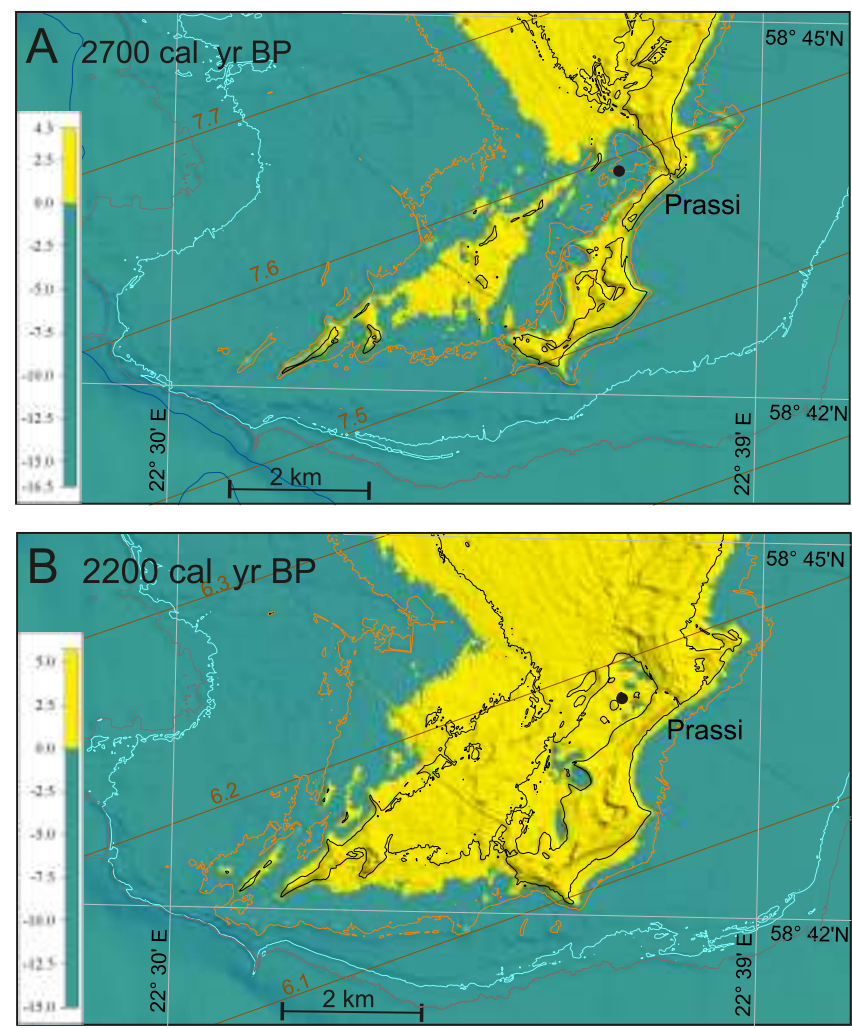

Fig. 8. 3D reconstructions at 2700 and $2200 \mathrm{cal} \mathrm{yr} \mathrm{BP}$ at Prassi (A, B)

For explanations see Figure 5

water lagoon was formed until about $8500 \mathrm{cal}$ yr BP, when the basin was finally isolated.

4. According to diatom records, the Loopsoo, Tihu and Prassi basins isolated gradually passing the transitional phase at 6800,4800 and 2500 cal yr BP, respectively.

5. Palaeogeographic reconstructions show that the isolation of the basins lasted about 500-800 years, being longer for the basins that isolated later.

6. GIS-based modelled isolation times are supported by radiocarbon dates, except for Prassi.

7. Water level curves for different sites in Hiiumaa follow a similar pattern, but the transgression maximum in areas of slower land uplift (Prassi) occurred later than in areas of faster uplift (Kõivasoo), showing a diachronous Early Litorina/Litorina transgression peak.

8. Water level curves display a linear decline during the last 8000 years.

Acknowledgements. The study was supported by the institutional research funding IUT 1-8, ESF Grant 9031 and Doctoral Studies and Internationalisation Programme DoRa. We thank two anonymous reviewers for valuable comments and suggestions. 


\section{REFERENCES}

Andrén, E., Andrén, T., Sohlenius, G., 2000. The Holocene history of the south-western Baltic Sea as reflected in a sediment core from the Bornholm Basin. Boreas, 29: 233-250.

Cker, K., Eriksson, B., Grönlund, T., Kankainen, T., 1988. Sediment stratigraphy in the northern Gulf of Finland. Geological Survey of Finland Special Paper, 6: 101-117.

Battarbee, R., Jones, V.J., Flower, R.J., Cameron, N.G., Bennion, H., Carvalho, L., Juggins, S., 2001. Diatoms. In: Tracking Environmental Change Using Lake Sediments, Vol. 3 : Terrestrial, Algal, and Siliceous Indicator (eds. J.P. Smol, H.J.B. Birks and W. Last): 155-202. Kluwer Academic Publishers.

Berglund, B.E., Sandgren, P., Barnekow, L., Hannon, G., Jiang, H., Skog, G., Yu, S.-Y., 2005. Early Holocene history of the Baltic Sea, as reflected in coastal sediments in Blekinge, southeastern Sweden. Quaternary International, 130: 111-139.

Bronk Ramsey, C., 2008. Deposition models for chronological records. Quaternary Science Reviews, 27: 42-60.

Bronk Ramsey, C., 2009. Bayesian analysis of radiocarbon dates. Radiocarbon, 51: 337-360.

Eltermann, G., 1993a. Glacial retreat from the West Estonian archipelago (in Estonian). Eesti Loodus, 5/6: 218-219.

Eltermann, G., 1993b. Hiiumaa according to geologist glimpse (in Estonian). Eesti Loodus, 3: 103-105.

Eronen, M., 1974. The history of the Litorina Sea and associated Holocene events. Societas Scientiarum Fennica, Commentationes Physico-Mathematicae, 44: 79-195.

Grimm, E., 2011. Tilia software v. 1.7.16. Illinois State Museum. Research and Collection Center, Springfield.

Grudzinska, I., Saarse, L., Vassiljev, J., Heinsalu, A., Veski, S., 2012. A palaeocoastline reconstruction for the Käsmu and Pärispea peninsulas (northern Estonia) over last 4000 years. Estonian Journal of Earth Sciences, 61: 307-316.

Grudzinska, I., Saarse, L., Vassiljev, J., Heinsalu, A., 2013. Midand late-Holocene shoreline changes along the southern coast of the Gulf of Finland. Bulletin of the Geological Society of Finland, 85: 19-34.

Haila, H., Sarmaja-Korjonen, K., Uutela, A., 1991. Development of a Litorina Bay at Espoo, near Porvoo, southern Finland. Bulletin of the Geological Society of Finland, 63: 105-119.

Hang, T., Kokovkin, T., 1999. Simulation of the Post-Glacial Baltic Sea Shorelines on Hiiumaa Island, West Estonian Archipelago. Proceedings of the Estonian Academy of Sciences, Geology, 48: 99-109.

Harff, J., Endler, R., Emelyanov, E., Kotov, S., Leipe, T., Moros, M., Olea, R., Tomczak, M., Witkowski, A., 2011. Late Quaternary climate variations reflected in Baltic Sea sediments. In: The Baltic Sea Basin (eds. J. Harff, S. Bjöck and P. Hoth): 99-132. Springer-Verlag, Berlin, Heidelberg.

Hyvärinen, H., 1984. The Mastogloia stage in the Baltic Sea history: diatom evidence from Southern Finland. Bulletin of the Geological Society of Finland, 56: 99-115.

Hyvärinen, H., 2000. The History of the Baltic Sea. Lundqua Report, 37: 45-54.

Hyvärinen, H., Donner, J., Kessel, H., Raukas, A., 1988. The Litorina Sea and Limnea Sea in the northern and central Baltic. Annales Academiae Scientiarum Fennicae, Series A. III, Geologica-Geographica, 148: 25-35.

Hyvärinen, H., Raukas, A., Kessel, H., 1992. Mastogloia and Litorina Seas (in Russian with English summary). In: Geology of the Gulf of Finland (eds. A. Raukas and H. Hyvärinen): 296-312. Estonian Academy of Sciences, Tallinn.

Ignatius, H., Axberg, S., Niemistö, L., Winterhalter, B., 1981 Quaternary geology of the Baltic Sea. In: The Baltic Sea (ed. A. Voipio): 54-104. Elsevier, Amsterdam.

Kadastik, E., 2004. Upper-Pleistocene Stratigraphy and Deglaciation History in Northwestern Estonia. Ph.D. Thesis. Universitatis Tartuensis, 15. Tartu University Press, Tartu.
Kadastik, E., Kalm, V., 1998. Lithostratigraphy of Late Weichselian tills on the West Estonian islands. Bulletin of the Geological Society of Finland, 70: 5-17.

Kalm, V., Kadastik, E., 2001. Waterlain glacial diamicton along the Palivere ice-marginal zone on the West Estonian Archipelago, eastern Baltic Sea. Proceedings of the Estonian Academy of Science, Geology, 50: 114-127.

Kents, P., 1939. Postglacial oscillations of the shoreline of the Baltic Sea in Estonia illustrated by the Kõpu Peninsula (in Estonian). Manuscript in Estonian State Archives, Tartu.

Kessel, H., Pork, M., 1974. On the age of some coastal lakes of the Baltic sea and the character of the diatom flora in west Estonia (in Russian with English summary). Hydrobiological Researches, VI: 26-50. Academy of Science of the Estonian SSR, Institute of Zoology and Botany, Tartu.

Kessel, H., Raukas, A., 1967. The Deposits of Ancylus Lake and Litorina Sea in Estonia (in Russian with English summary). Valgus, Tallinn.

Kessel, H., Raukas, A., 1979. The Quaternary history of the Baltic. Estonia. In: The Quaternary History of the Baltic (eds. V. Gudelis and L.-K. Königsson): 127-146. Acta Universitatis Upsaliensis, Uppsala.

Krammer, K., Lange-Bertalot, H., 1986. Bacillariophyaceae 1. Teil Naviculaceae. In: Süsswasserflora von Mitteleuropa 2/1 (eds. H. Ettl, J. Gerloff, H. Heying and D. Mollenhauser). Gustav Fischer Verlag, Stuttgart.

Krammer, K., Lange-Bertalot, H., 1988. Bacillariophyaceae 2. Teil Bacillariaceae, Epithemiaceae, Surirellaceae. In: Süsswasserflora von Mitteleuropa 2 (eds. H. Ettl, J. Gerloff, H. Heying and D. Mollenhauser). Gustav Fischer Verlag, Stuttgart.

Krammer, K., Lange-Bertalot, H., 1991a. Bacillariophyaceae 3. Teil Centrales, Fragilariceae, Eunotiaceae. In: Süsswasserflora von Mitteleuropa 2/3 (eds. H. Ettl, J. Gerloff, H. Heying, and D. Mollenhauser). Gustav Fischer Verlag, Stuttgart.

Krammer, K., Lange-Bertalot, H., 1991b. Bacillariophyaceae 4. Teil Achnanthaceae. In: Süsswasserflora von Mitteleuropa 2/4 (eds. H. Ettl, J. Gerloff, H. Heying and D. Mollenhauser). Gustav Fischer Verlag, Stuttgart.

Kriiska, A., Lõugas, L., 1999. Late Mesolithic and Early Neolithic Seasonal Settlement at Kõpu, Hiiumaa Island, Estonia. PACT, 57: 157-172.

Königsson, L.-K., 1968. The Holocene history of Grand Alvar of Öland. Acta Phytogeographica Suecica, 55.

Königsson, L.-K., Saarse, L., Veski, S., 1998. Holocene history of vegetation and landscape on the Kõpu Peninsula, Hiiumaa Island, Estonia. Proceedings of the Estonian Academy of Science, Geology, 47: 3-19.

Last, W. M., 2001. Textural analysis of lake sediments. In: Tracking Environmental Change Using Lake Sediments. Volume 2: Physical and Geochemical Methods (eds. W.M. Last and J.P. Smol): 41-81. Kluwer Academic Publishers, Dordrecht.

Liiva, A., Ilves, E., Punning, J.-M., 1966. Verzeichnis der im Institut für Zoologie und Botanik der Akademie der Wissenschaften der Estnischen SSR mittels der Radiokohlenstoff-Methode Datierten Proben (in Russian with German summary). Eesti NSV Teaduste Akadeemia Toimetised, Bioloogiline seeria, 1: 112-122.

Lindén, M., Möller, P., Björck, S., Sandgren, P., 2006. Holocene shore displacement and deglaciation chronology in Norrbotten, Sweden. Boreas, 35: 1-22.

Luha, A., Blumfeldt, E., Tammekann, A., 1934. Saaremaa. Geographical, Economocal and Historical Description (in Estonian). Eesti Kirjanduse Seltsi kirjastus, Tartu.

Miettinen, A., 2002. Relative sea level changes in the eastern part of the Gulf of Finland during the last 8000 years. Annales Academy Scientiarum Fennicae, Geologica-Geographica, 162: $1-102$. 
Miettinen, A., 2004. Holocene sea-level changes and glacio-isostasy in the Gulf of Finland, Baltic Sea. Quaternary International, 120: $91-104$

Miettinen, A., Hyvärinen, H., 1997. Stratigraphical evidence of Baltic water level changes between 8 and 6 ka BP in a small lake basin on the coast of the Gulf of Finland, SE Finland. Bulletin of the Geological Society of Finland, 69: 43-53.

Molodkov, A., Raukas, A., 1996. ESR Dating of Subfossil Mollusc Shells of the Limnea Sea. Baltica, 9: 29-35.

Moora, T., Lõugas, L., 1995. Natural condition at the time of primary habitation of Hiiumaa Island. Proceedings of the Estonian Academy of Sciences, Humanities and Social Sciences, 44: 472-481.

Mäemets, A., 1977. Estonian Lakes and their Protection (in Estonian with English summary). Valgus, Tallinn.

Mörner, N.-A., 1979. The Fennoscandian uplift and Late Cenozoic in geodynamics: geological evidence. GeoJournal, 3: 287-318.

Orru, M., 1995. Estonian Mires. Handbook (in Estonian with English summary). Geological Survey of Estonia, Tallinn.

Ratas, U., 1976. On the formation of the landscape of Hiiumaa island and its surrounding islets. In: Estonia. Regional Studies (ed. A. Raukas): 104-113. Valgus, Tallinn.

Raukas, A., Ratas, U., 1996. Holocene evolution and palaeoenvironmental conditions of Hiiumaa Island, northwestern Estonia. PACT, 50: 167-174.

Raukas, A., Kessel, H., Hyvärinen, H., 1992. Limnea Sea (in Russian with English summary). In: Geology of the Gulf of Finland (eds. A. Raukas and H. Hyvärinen): 312-317. Estonian Academy of Sciences, Tallinn.

Raukas, A., Tavast, E., Molodkov, A., 1996. Partsi - a new promising area for the investigation of Late Boreal and early Atlantic sea level changes of the Baltic Sea. Proceedings of the Estonian Academy of Sciences, Geology, 45: 92-101.

Reimer, P.J., Bard, E., Bayliss, A., Beck, J.W., Blackwel, P.G., Bronk Ramsey, C., Buck, C.E., Cheng, H., Edwards, R.L., Friedrich, M., Groots, P.M., Guilderson, T.P., Haflidason, H., Hajdas, I., Hatte, C., Heaton, T.J., Hoffman, D.L., Hogg, A.G., Hughen, K.A., Kaiser, K.F., Kromer, B., Manning, S.W., Niu, M., Reimer, R.W., Richards, D.A., Scott, E.M., Southon, J.R., Staff, R.A., Turney, C.S.M., van der Plicht, J., 2013. IntCal13 and Marine13 radiocarbon age calibration curves $0-50,000$ years cal BP. Radiocarbon, 55: 1869-1887.

Risberg, J., Alm, G., Goslar, T., 2005. Variable isostatic uplift patterns during the Holocene in southeast Sweden, based on high-resolution AMS radiocarbon dating of lake isolations. The Holocene, 15: 847-857.

Rosentau, A., Vassiljev, J., Hang, T., Saarse, L., Kalm, V., 2009. Development of the Baltic Ice Lake in the eastern Baltic. Quaternary International, 206: 16-23.

Rosentau, A., Muru, M., Kriiska, A., Subetto, D.A., Vassiljev, J., Hang, T., Gerasimov, D., Nordqvist, K., Ludikova, A., Lõugas, L., Raig, H., Kihno, K., Aunap, R., Letyka, N., 2013. Stone Age settlement and Holocene shore displacement in the Narva-Luga Klint Bay area, eastern Gulf of Finland. Boreas, 42 912-931.

Saarse, L., 1994. Bottom deposits of small Estonian lakes (in Russian with English summary). Estonian Academy of Sciences, Institute of Geology, Tallinn.

Saarse, L., Heinsalu, A., Karhu, J., Vassiljev, J., Veski, S., 2000. Holocene shoreline displacement and palaeogeography of the Kõpu Peninsula, Hiiumaa, Estonia. Baltica, 13: 15-23.
Saarse, L., Heinsalu, A., Veski, S., 2009. Litorina Sea sediments of ancient Vääna Lagoon, northwestern Estonia. Estonian Journal of Earth Sciences, 58: 85-93.

Saarse, L., Heinsalu, A., Veski, S., 2012. Deglaciation chronology of the Pandivere and Palivere ice-marginal zones in Estonia. Geological Quarterly, 56 (2): 353-362.

Saarse, L., Vassiljev, J., Miidel, A., 2003. Simulation of the Baltic Sea shorelines in Estonia and neighbouring areas. Journal of Coastal Research, 19: 261-268.

Saarse, L., Vassiljev, J., Miidel, A., Niinemets, E., 2006. Holocene buried organic sediments in Estonia. Proceedings of the Estonian Academy of Sciences, Geology, 55: 296-320.

Saarse, L., Vassiljev, J., Heinsalu A., 2010. Reconstruction of the land ea changes on the Juminda Peninsula, North Estonia, during the last 10300 years. Baltica, 23: 117-126.

Sarv, A., 1981. Geochronological subdivision of Holocene bog-lacustrine deposits in the region of Kõivasoo swamp (Hiiumaa island, Estonia) (in Russian with English summary). Proceedings of the Academy of Sciences, Geology, 30: 173-178.

Sarv, A., Pork, M., Ilves, E., 1982. Stratigraphy and chronology of lake and bog deposits of the Kõivasoo bog. In: Peatland Ecosystems (ed. V. Masing): 148-163. Valgus, Tallinn.

Sepp, U., 1974. Character of the landscape of Hiiumaa (in Estonian with English and Russian summaries). Valgus, Tallinn.

Seppä, H., Tikkanen, M., 1998. The isolation of Kruunuvuorenlampi, southern Finland, and implication for Holocene shore displacement models of the Finnish south coast. Journal of Paleolimnology, 19: 385-398.

Seppä, H., Tikkanen, M., Shemeikka, P., 2000. Late-Holocene shore displacement of the Finnish south coast: diatom, lithoand chemostratigraphic evidence from three isolation basins. Boreas, 29: 219-231.

Snoeijs, P., 1993. Intercalibration and Distribution of Diatom Species in the Baltic Sea 1. Opulus Press, Uppsala.

Snoeijs, P., Balashova, J., 1998. Intercalibration and Distribution of Diatom Species in the Baltic Sea 5. Opulus Press, Uppsala.

Snoeijs, P., Kasperovičienè, J., 1996. Intercalibration and Distribution of Diatom Species in the Baltic Sea 4. Opulus Press, Uppsala.

Snoeijs, P., Potapova, M., 1995. Intercalibration and Distribution of Diatom Species in the Baltic Sea 3. Opulus Press, Uppsala.

Snoeijs, P., Vilbaste, S., 1994. Intercalibration and Distribution of Diatom Species in the Baltic Sea 2. Opulus Press, Uppsala.

Svensson, N.-O., 1989. Late Weichselian and early Holocene shore displacement in the central Baltic, based on stratigraphical and morphological records from eastern Småland and Gotland, Sweden. Lundqua Thesis, 25.

Thomson, P.W., 1929. Die Regionale Entwicklungsgeschichte der Wälder Estlands. Publications of the Geological Institution of the University of Tartu, 19: 1-87.

Torim, A., 2004. On the land uplift and changes in the coastline of Estonia (in Estonian). Geodeet, 28: 57-62.

Veski, S., Heinsalu, A., Klassen, V., Kriiska, A., Lõugas, L., Poska, A., Saluäär, U., 2005. Early Holocene coastal settlement and palaeoenvironment on the shore of the Baltic Sea at Pärnu, southwestern Estonia. Quaternary International, 130: 75-85.

Witkowski, A., 1994. Recent and fossil diatom flora of the Gulf of Gdańsk, Southern Baltic Sea. Bibliotheca Diatomologica, 28.

Witkowski, A., Lange-Bertalot, H., Metzeltin, D., 2000. Diatom Flora of Marine Coasts I. Iconographia Diatomologica 7. A.R.G. Gantner Verlag K.G., Ruggell, Liechtenstein. 